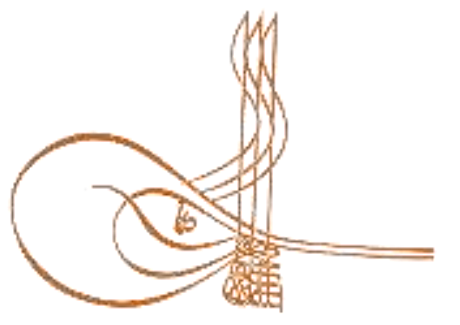

www.turkishstudies.net/turkishstudies
Turkish Studies

eISSN: $1308-2140$

Research Article / Araştırma Makalesi

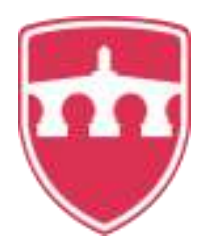

INTERNATIONAL

BALKAN

UNIVERSITY

Sponsored by IBU

\title{
Zihinsel Yetersizliği Olan Öğrencilere Okuma-Yazma Öğretilirken Karşılaşılan Güçlükler ve Geliştirilen Stratejiler*
}

\author{
Difficulties in Teaching Reading and Writing to Student with Intellectual Disability and Developed \\ Strategies About This Issue
}

\author{
Kismet Deliveli**
}

\begin{abstract}
The purpose of this study by referring to the opinions of teachers working in primary school, while they face while teaching literacy to the students with intellectual disabilities is to determine the strategies they have developed in solving the problems. For this purpose, a qualitative research approach of phenomenological research methods was used. In the creation of the study group, the criterion sampling method from purposeful sampling methods was used and 13 teachers who had mentally disabled students were reached. The data was obtained through a semi-structured interview form and the classroom teachers who voluntarily supported the research during the interviews were asked to answer 6 open-ended questions in the interview form. In order to provide the validity and reliability criteria sought in qualitative research, credibility, consistency, transferability and confirmability criteria were taken into consideration. The data were analyzed using content analysis and descriptive analysis techniques. Participants' views are combined into common themes, while excerpts from participants' views are presented. The findings of the research were evaluated in four themes: 'the approach teachers adopted during the process of reading and writing, the problems they faced, the strategies they applied and the suggestions they developed'. Inthe present study, it is understood that all of the teachers adopt a studentoriented approach to conduct reading-writing activities, and take the needs of the students with mental disabilities into account. The teachers that focus on the adequacies of the students rather than their inadequacies while conducting reading-writing activities are observed to prefer such practices as the ones that are based on individual differences. That is already understood from the different practices conducted by the teachers 'while selecting methods, using tools-materials, and arranging activities.'
\end{abstract}

Structured Abstract: According to contemporary education approach, children with mental disabilities in terms of their interests, talents and levels of skills based on their levels of intelligence need their educational needs to be fulfilled when they are of school age. The duty that is to be undertaken by teachers in reading and writing activities is to take the characteristics of the students with mental disabilities for whom the process of learning takes longer and becomes challenging into consideration, and to help them achieve in basic knowledge and skills such as reading and writing by constantly paying attention to the performance levels of such students.

\footnotetext{
* Makalenin ilk hali 6. Uluslararası Sosyal Bilimler Kongresi'nde bildiri olarak sunulmuştur.

** Öğr. Gör. Dr., Muğla Sitkı Koçman Üniversitesi, Eğitim Fakültesi, Temel Eğitim

Lec. Dr., Mugla Sitku Koçman University, Faculty of Education, Department of Basic Education ORCID 0000-0003-3035-7505

dkismet@mu.edu.tr

Cite as/ Atıf: Deliveli K. (2020). Zihinsel yetersizliği olan öğrencilere okuma-yazma öğretilirken karşılaşılan güçlükler ve geliştirilen stratejiler, Turkish Studies, 15(2), 865-889. https://dx.doi.org/10.29228/TurkishStudies.39883

Received/Geliş: 24 November/Kasım 2019

Checked by plagiarism software

Accepted/Kabul: 25 April/Nisan 2020

Published/Yayın: 30 April/Nisan 2020

Copyright (C) MDE, Turkey 
It can of benefit to give the children with mental disabilities that display characteristics different than their peers and have cognitive inadequacies the opportunity to learn, and to enrich such students' learning environment.

At this point, the know-how and experiences that a teacher has, the tools and materials that is used, the method/methods preferred and the activities conducted in classroom/strategies developed are all effective in creating the class setting that is fit for the needs of the children with mental disabilities who have special needs. In fact, when teachers experience that the methods/practices that are performed are not actually suitable/adequate for the students with mental disabilities, they can develop special strategies based on the problems that have been detected to be experienced by their students while teaching them how to read and write or try out some special methods/practices that are suitable for such students' developmental characteristics. It can, therefore, contribute to the literature for teachers to share the practices that they conducted successfully in their classrooms to teach their special students how to read an write. Moreover, presenting the practices conducted by experienced teachers and the strategies developed by them based on their observations of their students while teaching their students how to read and write can guide young teachers that are seeking solutions for the problems faced by their students with mental disabilities while teaching them how to read and write so they can offer their students opportunities to learn.

\section{Purpose}

The purpose of this study by referring to the opinions of teachers working in primary school, while they face while teaching literacy to the students with intellectual disabilities is to determine the strategies they have developed in solving the problems.

\section{Participants}

For this purpose, a qualitative research approach of phenomenological research methods was used. In the creation of the study group, the criterion sampling method from purposeful sampling methods was used and 13 teachers who had mentally disabled students were reached.

\section{Data Collection}

The data was obtained through a semi-structured interview form and the classroom teachers who voluntarily supported the research during the interviews were asked to answer 6 open-ended questions in the interview form. In order to provide the validity and reliability criteria sought in qualitative research, credibility, consistency, transferability and confirmability criteria were taken into consideration. The data were analyzed using content analysis and descriptive analysis techniques. Participants' views are combined into common themes, while excerpts from participants' views are presented. The findings of the research were evaluated in four themes: 'the approach teachers adopted during the process of reading and writing, the problems they faced, the strategies they applied and the suggestions they developed'

\section{Discussion and Results}

In the present study, it is understood that all of the teachers adopt a student-oriented approach to conduct reading-writing activities, and take the needs of the students with mental disabilities into account. The teachers that focus on the adequacies of the students rather than their inadequacies while conducting readingwriting activities are observed to prefer such practices as the ones that are based on individual differences. That is already understood from the different practices conducted by the teachers 'while selecting methods, using tools-materials, and arranging activities.' The teachers express that students with mental disabilities have difficulty in learning while they are implementing the stages of the 'Sound-Based Sentence Method'. It is also observed that, to teach students with mental disabilities, some teachers resort to some strategies such as 'trying different methods/practices, 'making students repeat sound-spell-sentence formations, 'using visual-audial tools, practicing dictation, 'making students write using pencils of different colors. When asked what sorts of strategies work to get their opinions, all of the teachers presented their recommendations stating, "combined methods should be used, different tools should be used, students' attention should be caught, students should be rewarded so they are motivated," while some among these teachers state that "the order of the sounds should be changed in the Sound-Based Sentence Method." Different from these opinions, there are other opinions submitted by some teachers that have developed strategies to boost social skills; and they state that, "there should be an assistant teacher in classroom/school, students with mental disabilities should not be separated from other students so they are integrated with the class, students should be communicated." These results 
indicate that, in classrooms with students with mental disabilities, different practices should be considered and different strategies should be developed to teach such students how to read and write.

In conclusion, no matter how they are classified (by their levels of intelligence, highly slow, slow, teachable and educable/or by their educational needs, mild, average, slow and severely mentally-disabled), it is understood that children with mental disabilities need different practices in teaching how to read and write. Therefore, it is necessary to present specific reading-writing practices tailored for individual characteristics of such students to the literature. In the present study, to select teachers for the working group, it was important for these teachers to have a professional background of at least 6 years since the strategies developed by such teachers can be effective thanks to their professional experiences, and to be specialized in teaching students with mental disabilities how to read and write. The study is intended to present the practices conducted, problems faced, and strategies developed by the teachers, each of whom works at different schools, while teaching mildly-, medium-, and severely-mentally disabled students, as well as to share these teachers' experiences. Different from the present study, other studies that can be carried out based on quantitative and qualitative patterns and with different sample groups can determine how the process of teaching how to read and write is performed in classrooms with students with mental disabilities, and what sorts of practices are of use to get positive results. The methods developed/practiced by teachers to meet the educational needs of special children in teaching how to read and write, or different practices (quantitative-experimental or qualitative research-action researches, single subject patterned qualitative researches), if any, can be searched for and the results from them can be discussed. All of the results to be shared can be effective in developing/trying methods of reading-writing for student with mental disability, and in presenting new methods for the literatüre.

Keywords: Teacher traning, Primary School, Student with Intellectual Disability, Literacy Teaching, Strategies.

Öz: Bu çalışmanın amacı, ilkokulda görev yapan öğretmenlerin görüşlerine başvurarak genel ve özel eğitim sınıflarında zihinsel yetersizliği olan öğrencilere okuma yazmayı öğretirken karşılaştıkları sorunların çözümünde geliştirdikleri stratejileri belirleyebilmektir. Bu amaç için nitel bir araştırma yöntemi olan fenomolojik araştırma yaklaşımından yararlanılmıştır. Çalışma grubu oluşturulurken, amaçlı örnekleme yöntemlerinden ölçüt örnekleme yöntemi kullanılmış ve sınıfında zihinsel yetersizliği olan öğrencisi/öğrencileri bulunan 13 öğretmene ulaşılmıştır. Veriler, yarı yapılandırılmış görüşme formu ile elde edilmiş ve görüşmeler sırasında araştırmaya gönüllü olarak destek veren sınıf öğretmenlerinin yarı yapılandırılmış görüşme formunda bulunan 6 açık uçlu soruya cevap vermeleri istenmiştir. Araştırmada, nitel araştırmalarda aranan geçerlik ve güvenirlik ölçütlerini sağlamak amacıyla, inandırıcılık, tutarlık, aktarılabilirlik ve teyit edilebilirlik ölçütleri göz önünde bulundurulmuştur. Elde edilen veriler içerik analizi ve betimsel analiz tekniğiyle analiz edilmiştir. Katılımcı görüşleri ortak temalar halinde birleştirilirken, katılımcı görüşlerinden alıntılar sunulmuştur. Araştırma bulguları 'öğretmenlerin okuma-yazma öğretim sürecinde benimsedikleri yaklaşım, karşılaştıkları sorunlar, uyguladıkları stratejiler ve geliştirdikleri öneriler’ olmak üzere dört temada değerlendirilmiştir. Bu çalışmada öğretmenlerin tamamının, öğrenci merkezli bir yaklaşım benimseyerek okuma-yazma etkinliklerini zihinsel yetersizliği olan öğrencinin gereksinimlerini göz önünde bulunduracak şekilde gerçekleştirdikleri anlaşılmıştır. Çocuğu merkeze alan bir yaklaşımla, öğrencinin yetersizliklerine değil yeterliliklerine bağlı olarak gerçekleştirdikleri okuma-yazma etkinliklerinde öğretmenlerin ‘yöntemleri seçerken, araç-gereçleri kullanırken, etkinlikleri düzenlerken' farklı uygulamalara yer vermeye çalıştıkları anlaşılmıştır

Anahtar Kelimeler: Öğretmen Yetiştirme, İlkokul, Zihinsel Yetersizliği Olan Öğrenciler, Okuma-Yazma Öğretimi, Stratejiler.

\section{Giriş}

Zihinsel gelişiminde meydana gelen yavaşlama, duraklama veya gerileme sebebiyle davranış ve uyumlarında yaşıtlarına göre sürekli gerilik ve yetersizliği olanlara zihinsel yetersizliği olan bireyler denilmektedir (Sucuoğlu, 2013). Zihinsel yetersizliği olan bireyler zeka bölümlerine ya da eğitsel ihtiyaçlarına göre sınıflandırılmakta bu yolla ne tür sorunlar olduğu ve ne tür eğitime 
ihtiyaçları olduğu açıklanmaktadır. Literatürde zeka seviyelerine göre 'çok ağır, ağır, öğretilebilir ve eğitilebilir' şeklinde değerlendirilebildiği gibi (Sinclaire ve Forness, 1983), Amerikan Zeka Geriliği Komitesi-AAMR ve 'Amerikan Psikiyatri Birliği ve Amerikan Zeka Yetersizliği Birliği'nin (American Association on Mental Deficiency, AAMD) yaptığı sinıflamaya dayanarak 'hafif, orta, ağır ve ileri derece zihinsel engelliler' biçiminde de incelenebilmektedir (1983; Köroğlu, 1997; Uyanık ve Tural, 2003; (MEGEP [Mesleki Eğitim ve Öğretim Sisteminin Güçlendirilmesi Projesi], 2016). Buna göre 'eğitilebilir grubunda' hafif düzeyde zihinsel gelişme geriliği olanların, 'öğretilebilir grubunda' orta düzeyde zihinsel gelişme geriliği olanların 'öz bakım grubunda' da ağır ve ileri derecede zihinsel gelişme geriliği olanların durumları açıklanmaktadır (MEGEP, 2016). Literatürde hem psikolojik hem de eğitsel sınıflandırmalar yapılsa da 2018 yılında yayınlanan son Özel Eğitim Hizmetleri Yönetmeliği’nde dünyada da yaygın olarak kullanılan psikolojik sınıflandırmaya göre bu öğrencilerin özellikleri açıklanmaktadır. Buna göre; zeka bölümleri 55-69 arasında olanlar "hafif derecede zihinsel yetersizliği bireyler", zeka bölümleri 40-54 arasında olanlar 'orta derecede zihinsel yetersizliği bireyler'; zeka bölümleri 25-39 arasında olanlar 'ağır derecede zihinsel yetersizliği bireyler' ve zeka bölümleri 25 'in altında olanlar da 'çok ağır derecede zihinsel yetersizliği olan bireyler' olarak değerlendirilmektedir.

Gelişim sürecinde zihinsel işlevler bakımından normal gelişim gösteren çocuklardan önemli derecede gerilik ve uyumsal davranışlarda yetersizlik gösteren zihinsel yetersizliği olan çocuklar (Aral ve Gürsoy, 2007: 117-119) akademik yeterlilikleri özellikler açısından da yaşıtlarından anlamlı düzeyde farkl1l1k göstermektedirler (Mastropieri ve Scruggs, 2016; Özkan, Öncül ve Kaya, 2013). $\mathrm{Bu}$ nedenle öğrenme sürecinde bu çocukların bilişsel özelliklerinin göz önünde bulundurulması ve gereksinimlerinin karşılanmasının önemli olduğu vurgulanmaktadır. Bu çocukların hem uzun hem de kısa süreli bellekte bilgileri toplama ve bu bilgileri kullanma (MEGEP, 2016) ve öğrenilen bilgiye odaklanma ve uyaranları kontrol etme sorunları olduğundan, zihinsel yetersizliği olan öğrencilere bilgi sunulurken küçük adımlar ilkesine göre hareket edilmesi (Tekinarslan, 2010) ve eğitimde günlük hayatta karşılaşabilecekleri kavramların öğretimine öncelik verilmesi gerektiğine dikkat çekilmektedir (Alptekin, 2010).

Zihinsel yetersizliği olan çocuklarla ilgili yapılan araştırmalara bakıldığında bazı araştırmacıların (Köroğlu, 1997; Söhmen ve Türkbay, 2003) bu çocuklarda genel olarak konuşma ve dil sorunları, görme bozuklukları, işitme kaybı, epilepsi, serebral palsi gibi 'fiziksel engellerinin' olduğunu; 'psikiyatrik bozukluklar' kapsamında da kendini yaralama davranışı gösterebildiklerini, dikkat eksikliği ve hiperaktivite davranım, duygu durum, anksiyete, bozukluklarının olduğunu tespit ettikleri anlaşılmaktadır. Bilişsel yetersizlikler konusuna dikkat çeken bazı araştırmacıların da (Tekinarslan, 2010; Werts, Culatto ve Tomkins, 2007) zihinsel yetersizliği olan çocukların 'bellek, dikkat, dil akademik beceriler, biliş ötesi, güdülenme ve genelleme özellikleri' yönünden yaşıtlarına göre farklılaşmaların olduğuna dikkat çektiği görülmektedir. Bu nedenle araştırmacılar (Metin, 2015; Stefanic, 1996; Villanueva, Taylor, Therrien ve Hand, 2012) zihinsel yetersizliği olan öğrencilerin eğitiminde özel uygulamalar ile stratejilerin geliştirilmesi gerektiğini vurgulayarak; öğrenme sürecinde zihinsel yetersizliği olan öğrencilerin ihtiyaçlarını karşılayacak yöntem, teknik ve materyallerin kullanılması halinde zihinsel engelli öğrencilerin de akademik olarak ilerleyebileceklerini ileri sürmektedir.

Tıpk1 yaşıtları gibi zihin yetersizliği olan öğrencilere öğretilecek en temel becerilerden en önemlisi okur-yazarlık becerisidir (Cora-İnce,2007). Eğitim etkinliklerinin birçoğu okuma yazma, anlama, anlatma ve konuşma üzerine kurulmaktadır. Ayrıca temel işlevsel akademik becerilerden biri olan okur-yazarlık becerisinin kazanılması bireyin gündelik yaşamını kolaylaştırdığ gibi hem zihinsel gelişim ve dilsel gelişim alanlarını ve hem de diğer derslerdeki başarı düzeylerini etkileyebilmektedir. Araştırmacılar genel olarak okul çağında kazanılan okuma-yazma alışkanlığının çocukların dil ve zihinsel gelişimlerine büyük katkı sağladığını belirtmektedir (Teale ve Sulzby, 1986; Hall, 1987; Çelenk, 2005; Senemoğlu, 2005; Gander ve Gardiner, 2007; Sever Sever, Kaya ve 
Aslan, 2011; Keklik, 2011). Bireyin yaşamındaki başarısı bir ölçüde sahip olduğu okuma-yazma becerisinin niteliğiyle ölçülebildiğinden (Çelenk, 2005) ve okuma yazma becerisinin kazanılmasıyla bireyin topluma uyum sağlayabilmesi ve bağımsız olarak hareket edebilmesi mümkün olduğundan her öğrencinin işlevsel okuryazarlık seviyesine ulaşması önemsenmelidir (Akyol, 1997).

Okuryazarlıkla ilgili temel beceriler Türkçe dersinde verilmektedir. Bu dersin öğretiminin de yaşama dönük bir süreç içinde gerçekleşmesi gerekmektedir (Sever vd., 2011:12). Türkiye'de 2005 Türkçe programında yer alan Ses Temelli Cümle Yöntemi kullanılmaktadır. Öğretmenler de programda başka yöntem önerilmediği için, zihinsel yetersizliği olan çocuklara okuma yazmayı öğretirken normal gelişim gösteren çocuklar için kullanılan yöntemleri kullanmaktadır. Ancak bazı araştırmacılar (Aker, 2009; Arabac1, 2009; Arslan-Armutçu, 2008; Deniz, 2008; Döngel, 2009; Duman, 2006; Dündar, 2006; Güldenoğlu, 2008; Güler, 2008; Şengül ve Akçin, 2010) yaşıtlarından farklı özellikler gösteren bu çocukların bu yöntem ile okuma yazmayı öğrenirken zorlandığını ve farklı uygulamalara ihtiyaç duyduğunu ortaya koymuşlardır. Bu araştırmacılardan Aker (2009) öğretmenlerin, okuma yazma öğretiminde ses temelli cümle yöntemini kullandıklarını, zihinsel yetersizliği olan öğrencilerin yavaş okuyabildiklerini ve okuduğunu anlamada güçlük yaşadığını ortaya koymuştur. Döngel (2009) özel eğitim sınıf öğretmenleri ile yaptı̆̆ 1 araştırmasında, öğretmenlerin hafif düzeyde zihin yetersizliği olan öğrencilere yazmayı öğretirken farklı yöntem ve teknikleri bir arada kullanarak soruna çözüm getirmeye çalıştıklarını tespit etmiştir. Deniz (2008) özel eğitim sınıf öğretmenleriyle yaptığı araştırmasında, öğretmenlerin okuma-yazma öğretiminde, cümle yöntemi, ses temelli cümle yöntemi ve ses yöntemi ile karma yöntemi gibi farkl1 yöntemler kullandıklarını ortaya koymuştur. Zihinsel yetersizliği olan öğrencilerin farklı gelişimsel özelliklere sahip olması ve bu öğrencilerin hazırlanmış okuma-yazma ve diğer ders kitaplarının olmaması nedeniyle öğretmenlerin ortak bir yöntem kullanamadıklarını belirtmiştir. Şengül ve Akçin (2010) özel eğitim öğretmenleriyle yaptığı araştırmalarında okuma yazma öğretiminde öğretmenlerin tek bir yönteme bağlı kalmadıklarını fakat ağırlıklı olarak, ses ve cümle çözümleme yöntemlerini kullandıklarını tespit etmiştir. Türkiye'de zihinsel yetersizliği olan çocuklar için geliştirilen veya kullanılan özel bir yöntem olmadığı için, bu çocukların bilişsel ve öğrenme özelliklerinin dikkate alınarak yeni yöntemler geliştirilmesi gerektiğine dikkat çekmişlerdir. Bu noktada zihinsel yetersizliği olan çocuklar için genel ve özel eğitim sınıflarında görev yapan öğretmenlerin okuma yazma öğretiminde zihinsel yetersizliği olan çocuklar için ne tür uygulamalar yaptıkları ve ne tür stratejiler geliştirdiklerinin ortaya konulması yararlı olabilir. Ancak Türkiye'de yapılan çalışmalar incelendiğinde; genel ve özel eğitim sınıflarında görev yapan öğretmenlerin farklı düzeylerde zihinsel yetersizliği olan çocuklara okuma yazmayı öğretirken, karşılaştıkları sorunlara çözüm getirmek için ne tür uygulamalara yer verdikleri ve ne tür stratejiler geliştirdiklerine yönelik herhangi bir çalışma yapılmadığı tespit edilmiştir.

\section{Çalışmanın Amacı}

$\mathrm{Bu}$ çalışmanın amac1, ilkokulda görev yapan öğretmenlerin görüşlerine başvurarak genel ve özel eğitim sınıflarında zihinsel yetersizliği olan öğrencilere okuma yazmayı öğretirken karşılaştıkları sorunların çözümünde geliştirdikleri stratejileri belirleyebilmektir. Araştırma amacına bağlı olarak çalışmada aşağıdaki dört soruya yanıt aranmıştır.

1. Zihinsel yetersizliği olan öğrencilere okuma-yazmayı öğretirken öğretmenler benimsedikleri yaklaşım gereği neler yapmaktadır?

2. Zihinsel yetersizliği olan öğrencilere okuma-yazmayı öğretirken öğretmenlerin karşılaştıkları sorunlar nelerdir?

3. Zihinsel engelli öğrencilere okuma-yazmayı öğretirken öğretmenlerin geliştirdikleri stratejiler nelerdir? 
4. Zihinsel yetersizliği olan öğrencilere okuma-yazmayı öğretirken öğrenme sürecinin etkili olabilmesi için öğretmenler neler önermişlerdir?

\section{Yöntem}

Nitel araştırma yaklaşımına göre desenlenen bu araştırmada fenomenolojik yöntemden yararlanılmıştır. Nitel araştırmaların amacı sosyal dünyanın aktörleri olarak bireylerin içinde yaşadıkları dünyaya ilişkin algılarını yorumlayabilmektir. Bu nedenle çalışılan konu veya sorunu tecrübe eden kişilerin görüşlerine başvurulurken farklı nitel araştırma desenlerine başvurulabilmektedir (Creswell, 2012; Creswell, 2013: Glesne, 2012; Merriam, 2014). Bu desenlerden biri olan fenomenolojik yöntem kullanıldığında, araştırmacılar insanların yaşadıkları evrende karşılaştıkları fenomenleri nasıl algıladıkları ve neleri deneyimledikleriyle ilgilenirler. $\mathrm{Bu}$ tür araştırmalarda insanların doğal dünyayı kendi açılarından nasıl algıladıkları eleştirilmeksizin ya da doğru veya yanlış olarak değerlendirilmeksizin araştırılan fenemone yönelik görüşleri incelenmektedir. Fenomene ilişkin yapılan açıklamalar ise detaylı bir şekilde incelendikten sonra tema ve alt kategorilere ayrılarak incelenmektedir. Bu süreçte katılımcıların gerçekte nasıl algılayıp ne düşündükleri net biçimde ortaya konulmak istenmektedir (Koballa, Graber, Coleman ve Kemp, 2000; Yıldırım ve Şimşek, 2013; Punch, 2014).

\section{Çalıșma Grubu}

$\mathrm{Bu}$ araştırmada sınıfinda zihinsel yetersizliği olan öğrencisi bulunan 13 öğretmen çalışma grubunu temsil etmektedir. Çalışma grubu oluşturulmasında amaçlı örnekleme yöntemlerinden ölçüt örnekleme yöntemine başvurulmuştur. Amaçlı örnekleme yönteminde amaç küçük ve benzeşik belirgin bir alt grubu tanımlamaktır. Ölçüt örnekleme yönteminde ise araştırma kapsamında bir dizi ölçütü karşılayan durumların incelenmesi söz konusudur (Ritchie ve Lewis ve Elam, 2006; Yıldırım ve Şimşek, 2013). Bu bilgilerden hareketle çalışma grubuna karar verilirken, öğretmenlerin halihazırda zihinsel yetersizliği olan öğrencilerin olduğu sınıflarda çalışıyor olması ölçütü de esas alınmıştır. Ayrıca öğretmenlerin meslekte en az 6 yıllık çalışma geçmişi olmasına; zihinsel yetersizliği olan öğrencilere okuma yazma öğretimi konusunda uzmanlaşmış olmasına, çalışmayı gönüllü olarak destekleyen öğretmenlerle görüşmeler yapılmasına önem verilmiştir. Araştırmada katılımcılara okul adı, öğrenci özellikleri ve kişisel bilgilerin gizli kalacağı sözü verildiğinden kod adları 'adı, cinsiyeti, yaşı ve kıdem yılı' harf ve rakamlarla simgelenmiştir. Buna göre 'Ö1-K-28-6' araştırmaya birinci sırada katılan, 28 yaşında 6 yıllık mesleki tecrübesi olan kadın öğretmeni simgelemektedir. Tablo 1'de görülebileceği gibi her biri farkl1 okullarda öğretmenler 'hafif, orta, ağır' derecede zihinsel yetersizliği olan öğrencilerin eğitim gördüğü sınıflarda çalışmaktadır. Okul ve sınıfın imkanlarına göre 'genel eğitim ve özel eğitim sınıflarında' hizmet veren öğretmenlerin öğrenci sayıları da farklıdır. Aşağıda Tablo 1'de çalışma grubunu yansıtan genel bilgiler incelenebilir. 
Tablo1: Çalışma Gurubu ve Özellikleri

\begin{tabular}{|c|c|c|c|c|}
\hline 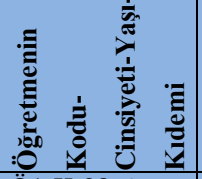 & Öğretmenin Branşı & Okul Adı & $\begin{array}{l}\text { Öğrencinin Zihin Engel Derecesi } \\
\text { Sınıftaki Zihinsel yetersizliği olan } \\
\text { Öğrenci Sayısı }\end{array}$ & 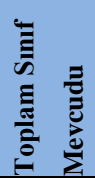 \\
\hline Ö1-K-28-6 & Sınıf Öğretmenliği & $\begin{array}{l}\text { HRM Okulu } \\
\text { Özel Eğitim Sınıfı }\end{array}$ & Ağır Derecede Zihinsel yetersizliği olan-1 & 1 \\
\hline Ö2-K-49-25 & Sınıf Öğretmenliği & $\begin{array}{l}\text { YG Okulu } \\
\text { Genel Eğitim Sınıfı }\end{array}$ & $\begin{array}{l}\text { Hafif Derecede Zihinsel yetersizliği olan- } \\
1\end{array}$ & 24 \\
\hline Ö3-E-40-16 & Sınıf Öğretmenliği & $\begin{array}{l}\text { BA Okulu } \\
\text { Genel Eğitim Sınıfi }\end{array}$ & $\begin{array}{l}\text { Hafif Derecede Zihinsel yetersizliği olan- } \\
1\end{array}$ & 13 \\
\hline Ö4-E-38-13 & Sınıf Öğretmenliği & $\begin{array}{l}\text { BA Okulu } \\
\text { Genel Eğitim Sınıfi }\end{array}$ & $\begin{array}{l}\text { Hafif Derecede Zihinsel yetersizliği olan- } \\
1\end{array}$ & 11 \\
\hline Ö5-K-31-8 & Özel Eğitim Öğretmenliği & $\begin{array}{l}\text { KS Okulu } \\
\text { Özel Eğitim Sınıfi }\end{array}$ & $\begin{array}{l}\text { Hafif Derecede Zihinsel yetersizliği olan- } \\
4 \\
\text { Orta Derecede Zihinsel yetersizliği olan-1 } \\
\text { Ağır Derecede Zihinsel yetersizliği olan-1 }\end{array}$ & 6 \\
\hline Ö6-K-36-6 & $\begin{array}{l}\text { Zihin Engelliler } \\
\text { Öğretmenliği }\end{array}$ & $\begin{array}{l}\text { U Okulu } \\
\text { Özel Eğitim Sınıfı }\end{array}$ & $\begin{array}{l}\text { Hafif Derecede Zihinsel yetersizliği olan- } \\
1 \\
\text { Ağır Derecede Zihinsel yetersizliği olan-1 }\end{array}$ & 2 \\
\hline Ö7-E-35-11 & Özel Eğitim Öğretmenliği & $\begin{array}{l}\text { E Okulu } \\
\text { Özel Eğitim Sınıfı }\end{array}$ & $\begin{array}{l}\text { Hafif Derecede Zihinsel yetersizliği olan- } \\
2 \\
\text { Orta Ağır Derecede Zihinsel yetersizliği } \\
\text { olan-1 }\end{array}$ & 3 \\
\hline Ö8-E-41-7 & Sınıf Öğretmenliği & $\begin{array}{l}\text { K Okulu } \\
\text { Genel Eğitim Sınıfi }\end{array}$ & Hafif Düzeyde Zihinsel yetersizliği olan-2 & 10 \\
\hline Ö9-K-30-9 & Sınıf Öğretmenliği & $\begin{array}{l}\text { V Okulu } \\
\text { Genel Eğitim Sınıfı }\end{array}$ & $\begin{array}{l}\text { Hafif Derecede Zihinsel yetersizliği olan- } \\
1\end{array}$ & 13 \\
\hline Ö10-K-38-11 & Sınıf Öğretmenliği & $\begin{array}{l}\text { T Okulu } \\
\text { Genel Eğitim Sınıfi }\end{array}$ & $\begin{array}{l}\text { Hafif Derecede Zihinsel yetersizliği olan- } \\
1\end{array}$ & 16 \\
\hline Ö11-E-36-14 & Sınıf Öğretmenliği & $\begin{array}{l}\text { A Okulu } \\
\text { Genel Eğitim Sınıfi }\end{array}$ & $\begin{array}{l}\text { Hafif Derecede Zihinsel yetersizliği olan- } \\
1\end{array}$ & 14 \\
\hline Ö12-E-33-11 & Özel Eğitim Öğretmenliği & $\begin{array}{l}\text { M Okulu } \\
\text { Özel Eğitim Sinıfı }\end{array}$ & $\begin{array}{l}\text { Hafif Derecede Zihinsel yetersizliği olan- } \\
7\end{array}$ & 9 \\
\hline Ö13-E-37-14 & Sınıf Öğretmenliği & $\begin{array}{l}\text { Ş Okulu } \\
\text { Genel Eğitim Sınıfi }\end{array}$ & $\begin{array}{l}\text { Hafif Derecede Zihinsel yetersizliği olan- } \\
1\end{array}$ & 35 \\
\hline
\end{tabular}

\section{Verilerin Toplanması}

Nitel araştırmalarda 'gözlem, görüşme ve doküman analizi' farklı veri toplama yöntemleri kullanılabilmektedir. Bu yolla olayı/olguyu katılımcıların nasıl algıları anlaşılabilmekte ve olaylar doğal ortamında gerçekçi ve bütüncül bir biçimde ortaya konulabilmektedir (Creswell, 2012; Creswell, 2013: Glesne, 2012). Bu çalışmada görüşme yöntemi ile zihinsel yetersizliği olan öğrencilerin olduğu sınıflarda görev yapan tecrübeli öğretmenlerin görüşleri incelenerek deneyimleri aktarılmak istenmiştir. Veriler öğretmenlerle yapılan görüşmeler sırasında kullanılan yarı 
yapılandırılmış görüşme formu ile elde edilmiştir. Görüşme formu hazırlanırken, araştırmanın amacı ve çalışmanın nasıl gerçekleştirileceği açık bir şekilde belirten ifadelere, araştırmaya katılacak olan öğretmenlerin demografik özellikleri ile ilgili 8 soru ile araştırma hedefine uygun 7 açık uçlu soruya yer verilmiştir. Görüşmelere başlamadan önce görüşme formlarındaki sorular alanda uzman olan iki akademisyen tarafından incelendikten sonra, soru sayısı 6'ya indirilmiştir. Hazırlık formundaki sorular 2 öğretmene sorulmak suretiyle soruların anlaşılırlığı test edildikten sonra görüşme formunun son şekline karar verilmiştir.

Çalışmaya katılımda gönüllülük esası dikkate alınmıştır. Araştırmaya destek veren ve kendileriyle görüşme yapılmasını kabul eden katılımcılara kimliklerinin saklı tutulacağ vurgulandıktan sonra, araştırmacı tarafindan oluşturulan yarı yapılandırılmış görüşme formunda bulunan 6 adet açık uçlu soruya katılımcıların yazılı olarak cevap vermeleri istenmiştir: Bu sorular; 1. Zihinsel yetersizliği olan öğrencilere okuma-yazmaya hazırlık sürecinde ne tür eğitim hizmetleri vermektesiniz? 2. Zihinsel yetersizliği olan öğrencilere okuma-yazmayı öğretirken, yaşadığınız temel sorunlar nelerdir? 3. Bu sorunlara yönelik geliştirdiğiniz stratejileriniz ve uygulamalarınız var ise biraz anlatabilir misiniz? 4. Ses Temelli Cümle Yöntemi'nin hangi aşamalarında, ne tip sorunlar yaşıyorsunuz? 5. Bu sorunların üstesinden gelmek için geliştirdiğiniz taktikleriniz/stratejileriniz varsa bilgilendirebilir misiniz? 6. Size göre okuma-yazma öğretiminde zihinsel yetersizliği olan öğrenciler için ne tip yöntemler kullanılmalıdır? Niçin?

\section{Verilerin Analizi}

Fenemolojik desene göre tasarlanan bu araştırmada sınıf öğretmenlerinin zihinsel yetersizliği olan öğrencilere okuma yazma öğretim sürecinde neleri deneyimledikleri konusuna odaklanıldığından, verilerin analizinde 'içerik analizi ve betimsel analiz' teknikleri kullanılmıştır (Yıldırım ve Şimşek, 2013). Fenomenolojik yöntemin odak noktasını kişinin öznel deneyimleri oluşturmaktadır. Bu tür araştırmalarda bireyin kişisel dünya görüşüyle ve olayları yorumlamasıyla yani, konu alanına ait fenomeni nasıl algıladığıla ilgilenilir (Marton, 1986; Punch, 2014). Veri analizleri yapılırken ise yaşantıları ve anlamları çıkarmayı amaçlayan bir yol izlenir. Bu amaç için başvurulan bir yöntem olan içerik analizi çözümlemelerinde elde edilen veriler kavramsallaştırılarak, olgu tanımlanır. Bu süreçte temalar ve kategoriler ortaya çıkarılmaya çalışılırken, sonuçlar betimsel bir anlatım ile sunulabilir doğrudan alıntılara yer verebilir (Yıldırım ve Şimşek, 2013). Bu bilgiler 1şığında öğretmen görüşlerinden elde edilen veriler temalar ile kodlar halinde belirlenirken, her bir temada katılımcı görüşlerinden alıntılar yapılmıştır. Katılımcı görüşlerinden alıntılar sunulurken ise, katılımcı simgesi eklenmiştir. Örneğin (Ö2-K-49-25) araştırmaya 2. Sırada katılan, 49 yaşında, 25 yıllık çalışma geçmişi olan kadın öğretmeni simgelemektedir.

\section{Araştırmada Geçerlik ve Güvenirlik}

Araştımada, nitel araştırmalarda aranan geçerlik ve güvenirlik ölçütlerini sağlamak amacıyla, inandırıcılık (iç geçerlik), aktarılabilirlik (dış geçerlik), tutarlık (iç güvenirlik)ve teyit edilebilirlik (dış güvenirlik) ölçütleri göz önünde bulundurulmuştur (Lincoln ve Guba, 1985; Creswell, 2013). Nitel araştırmalarda inandırıcıllğı artırabilmek için elde edilen veriler yorumlanırken gerçekliğin doğru olarak yansıtılmasına dikkat edilmesi gerekmektedir (Lincoln ve Guba, 1985). Bu nedenle bulgular sunulurken katılımcıların bakış açılarının doğru anlaşılıp, görüş ve deneyimlerinin doğru yansıtılmasına özen gösterilmelidir (Merriam ve Tisdell, 2015). Bu araştırmada inandırıcıllğı artırabilmek için katılımc1 görüşlerinden ayrıntılı betimlemelerin yapılmasına ve katılımcı özelliklerinin sunulmasına önem verilmiştir. Nitel araştırmalarda aktarılabilirlik ölçütünü karşılayabilmek için sonuçların diğer durum ve bağlamlara aktarılabilir olmasına önem verilmesi gerekmektedir (Lincoln ve Guba, 1985). Bu çalışmada bulgular sunulurken aktarılan görüşlerin doğru olarak yansıtılabilmesi için katılımcıların verdikleri cevaplar tek tek ve birbirinden bağımsız olarak incelendikten sonra ortak temalar altında birleştirilmiştir. Her bir temada detaylı bir şekilde katılımcı görüşleri betimlenirken doğrudan alıntılara da yer verilmiştir. Nitel 
araştırmalarda tutarlık ölçütünün karşılanabilmesi için bulgu ve yorumların sürekli karşılaştırılarak birbiriyle tutarlı olacak şekilde sunulması gerekmektedir (Lincoln ve Guba, 1985). Bu araştırmada tutarlılık ölçütünü karşılayabilmek için genel ve özel eğitim sınıfında görev yapan öğretmenlerin görüşlerinden elde edilen veriler analiz edilirken bulgular sürekli olarak karşılaştırılmıştır. Nitel araştırmalarda teyit edilebilirlik (doğrulanabilirlik) ölçütünün karşılanması için araştırmacı bulguları ortaya koyarken kişisel inanç veya önyargılarından uzaklaşmalı ve nesnel bir tutum takınarak araştırdığı fenomeni doğru bir şekilde yansıtmaya çalışmalıdır (Creswell, 2012). Bu araştırmada teyit edilebilirlik ölçütünü sağlayabilmek için araştırmacı nesnel bir tutum takınmaya özen göstererek, genel eğitim ve özel eğitim sınıfında görev yapan öğretmenlerin okuma yazma öğretim sürecinde karşılaștıkları sorunlar için ne tür stratejiler geliștirdiklerini yansız bir tutumla yansıtmaya çalışmıştır. Bulguların nesnel bir şekilde yansıtıldığının denetlenebilmesi için tüm verileri saklamıştır.

\section{Bulgular ve Yorum}

Zihinsel yetersizliği olan öğrencileri olan öğretmenlerin okuma-yazma sürecinde neleri tecrübe ettikleri konusunda detaylı bilgiler sunabilmek için öğretmen görüşlerinden alıntıların sunulduğu araştırma bulguları 'öğretmenlerin okuma-yazma öğretim sürecinde benimsedikleri yaklaşım, karşılaştıkları sorunlar, uyguladıkları stratejiler ve geliştirdikleri öneriler' olmak üzere dört temada değerlendirilmiştir (Şekil.1).

Şekil 1: Öğretmenlerin Okuma-Yazma Öğretimi Sürecine Yönelik Görüşleri
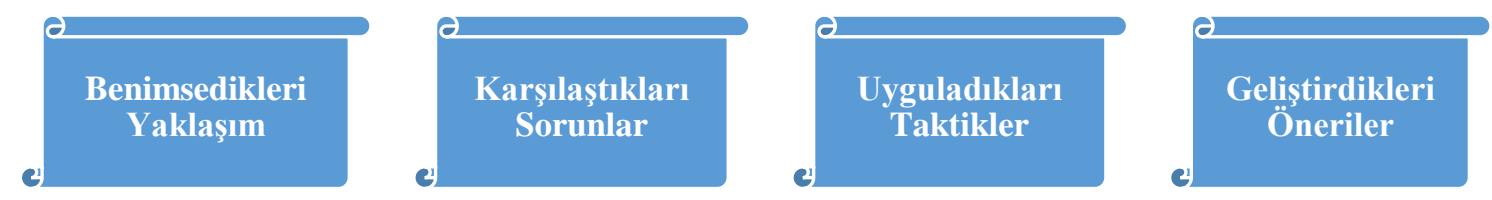

\section{Okuma-Yazma Öğretimin Sürecinde Benimsedikleri Yaklaşım}

Bu çalışmada görüşleri alınan öğretmenlerden sekizi (Ö2, Ö3, Ö4, Ö8, Ö9, Ö10, Ö11, Ö13) genel eğitim sınıfında ve beşi de (Ö1, Ö5, Ö6, Ö7, Ö12) özel eğitim sınıfında görev yapmaktadır. Görüşler değerlendirildiğinde öğretmenlerin tamamının, öğrenci merkezli bir yaklaşım benimseyerek okuma-yazma etkinliklerini zihinsel yetersizliği olan öğrencinin gereksinimlerini göz önünde bulunduracak şekilde gerçekleştirdikleri anlaşılmıştır. Öğretmenlerin çocuğu merkeze alan anlayışla öğrenme sürecinde öğrenci ihtiyaçlarını karşılamaya özen gösterdikleri tespit edilmiştir. Okuma yazma etkinlikleri sırasında öğrencinin yetersizliklerine değil, yeterliliklerine odaklanmaya önem verdikleri bu amaç için ise okuma-yazma öğretiminde 'yöntemleri seçerken, araç-gereçleri kullanırken, etkinlikleri düzenlerken' farklı uygulamalara da yer vermeye çalıştıklarını ifade ettikleri belirlenmiştir.

Yöntem seçimi konusuna bakıldığında, öğretmenlerin tamamının 'Ses Temelli Cümle Yöntemi'ni kullandıkları anlaşılmıştır. Ancak altı öğretmenin (Ö1, Ö5, Ö7, Ö9, Ö10, Ö11) 'Ses Temelli Cümle Yöntemi'ne ek; 'Ses ve Hece Yöntemi'ni kullandığı anlaşılmıştır. Genel eğitim sınıflarında görev yapan öğretmenlerden üçü (Ö9, Ö10, Ö11) 'Ses ve Hece' yöntemini bir arada kullanarak hafif düzeyde zihinsel yetersizliği olan birer öğrenciye okuma yazmayı öğretmeye çalışmaktadır. Yine genel eğitim sınıfında görev yapan bir sınıf öğretmen de (Ö8) 'Ses Temelli Cümle Yöntemi' ile beraber 'Ses ve Kelime Yöntemi'ni bir arada harmanlayarak karma yöntem uygulamalarına yer vererek hafif düzeyde zihinsel yetersizliği olan bir öğrencisine okuma yazmayı öğretmeye çalıştığı anlaşılmıştır. Özel eğitim sınıfinda görev yapan öğretmenlerden birinin (Ö1) ağır derecede zihinsel yetersizliği olan bir öğrenciye; bir öğretmenin (Ö5) dördü hafif ve birer de orta ve ağır olmak altı ögrenciye; bir diğer öğretmenin de (Ö7) hafif derecede iki ve orta ağır derecede 
zihinsel yetersizliği olan bir olmak üzere üç öğrenciye 'Ses ve Hece' yöntemlerini harmanlayarak okuma yazmayı öğretmeye çalıştığı tespit edilmiştir. Bu sonuçlar özel eğitim ve genel eğitim sınıflarında ikinci bir yöntem olarak daha çok 'Ses ve Hece'; yine genel eğitim sınıfinda 'Ses ve Kelime' yöntemlerinin bir arada üçüncü bir yöntem olarak kullanıldığını göstermektedir.

Araç-gereç kullanımına bakıldığında bu çalışmada öğretmenlerin zihinsel yetersizliği olan öğrencilere okuma-yazma öğretiminde araç-gereç kullanmanın önemli olduğuna işaret ettikleri belirlenmiştir. Kullandıkları araç-gereçlere örnek vermeleri istendiğinde ise, genel eğitim sınıfından bir (Ö3) ve özel eğitim sınıfından bir öğretmenin (Ö5) MEB tarafından önerilen kılavuz kitab1 kullandıklarını belirttikleri anlaşılmıştır. Genel eğitim sınıfında görev yapan öğretmenin (Ö3) hafif düzeyde zihinsel yetersizliği olan bir öğrencisi, özel eğitim sınıfinda görev yapan öğretmenin ise (Ö5) hafif, orta ve ağır derecede zihinsel yetersizliği olan altı öğrencisi bulunmaktadır. Özel eğitim sınıfında görev yapan bir öğretmenin de sınıfında bulunan ağır derecede zihinsel yetersizliği olan öğrencisi için ‘Özel Çocuklar İçin Resimlerle Okuyorum' (Ö1) kitabını izlediği anlaşılmıştır. Farklı araç-gereç kullanmanın önemine değinen özel eğitim öğretmenlerinden ikisinin de (Ö1 ve Ö6) yerine göre 'hareketli resimleri', ikisinin (Ö1,Ö6) 'resimli kartları, üçünün (Ö5, Ö6, Ö7) ve 'öğretmen yapımı görsel materyalleri' ikisinin (Ö5, Ö6) bilgisayardan yararlandığı anlaşılmıştır. Buna karşılık genel eğitim sınıfından üç öğretmenin (Ö8, Ö11, Ö12) bilgisayarı ve sadece bir öğretmenin (Ö9) öğretmen yapımı görsel materyalleri kullandıkları belirlenmiştir. Bu sonuçlar da genel eğitim sınıfında görev yapan öğretmenlere kıyasla özel eğitim öğretmenlerinin farklı araçları kullanma konusuna daha fazla önem verdiklerini ortaya koymaktadır.

Öğretmenlere ne tür etkinliklere yer verdikleri sorulduğunda ise bazı öğretmenlerin zihinsel yetersizliği olan öğrencilerin dikkatlerini çekmek ve 'Ses Temelli Cümle Yöntemi'nin uygulama aşamalarında öğrencilerin öğrenmesini kolaylaştırabilmek amacıyla farklı etkinliklere yer vermeye çalıştıkları anlaşılmıştır. Bu öğretmenlerden birinin öğretmenin (Ö1), 'eğlenceli etkinliklere', ikisinin (Ö1, Ö6) 'oyunlara' ve beşinin de (Ö1, Ö7, Ö10, Ö11, Ö12) 'eğitici oyunlara' yer verdikleri anlaşılmıştır. Bu sonuçlar da genel eğitim sınıfında görev yapan öğretmenlerden sadece ikisinin (Ö10, Ö11) eğitici oyunlara yer verdiklerini; buna karşılık özel eğitim sınıfında görev yapan öğretmenlerin 'oyunlar, eğitici oyunlar, eğlenceli etkinlikler' gibi farklı etkinliklere yer vererek öğrenme sürecini eğlenceli hale getirmeye çalıştıklarını göstermektedir.

Aşağıda Şekil 2'de açıklayıcı görsel sunulduktan sonra, konu ile ilgili öğretmen ifadelerinden örnek alıntılar aktarılmıştır. 
Şekil 2: Okuma-Yazma Öğretiminde Gerçekleştirilen Uygulamalar
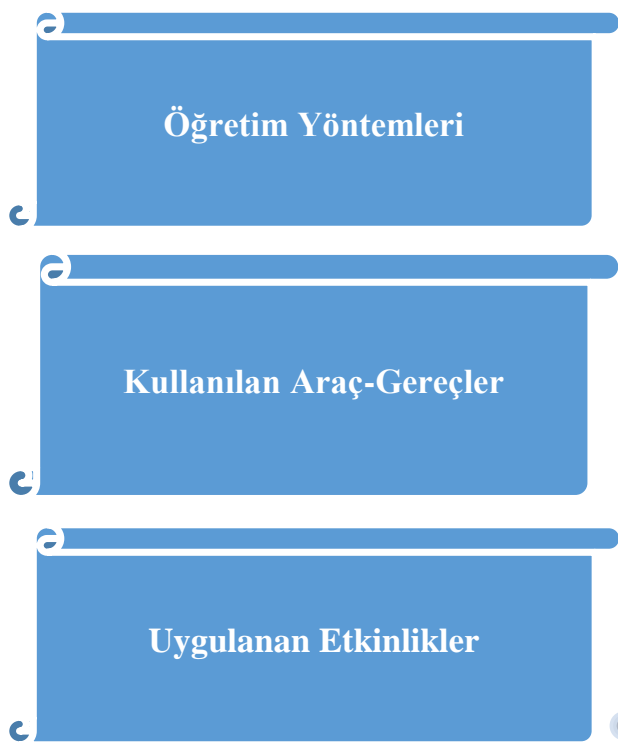

• Ses Temelli Cümle Yöntemi: Ö1, Ö2, Ö3, Ö4, Ö5, Ö6, Ö7, Ö8, Ö9, Ö10, Ö11, Ö12, Ö13

-Ses ve Hece Yöntemi: Ö1, Ö5, Ö7, Ö9, Ö10, Ö11

-Ses ve Kelime Yöntemi: Ö8

-Klavuz kitap: Ö3, Ö5

- Özel Çocuklar İçin Resimlerle Okuyorum Kitabı: Ö1

-Hareketli resimler: Ö1,Ö6

• Resimli kartlar: Ö1, Ö5, Ö6, Ö8, Ö11

- Öğretmen yapımı görsel materyaller: Ö5, Ö6, Ö7, Ö9

• Bilgisayar: (Ö5, Ö6, Ö8, Ö11, Ö12)

-Eğlenceli etkinlikler: Ö1

- Oyunlar: Ö1, Ö6

•Eğitici oyunlar: Ö1, Ö7, Ö10, Ö11, Ö12

‘Özel eğitim öğretmeniyim. Sinıfimdaki öğrencilerde dil ve konuşma bozukluğu, atipik otistik spektrum bozukluğu olan ögrencim dışında, hafif ve orta ă̆ır düzeyde zihinsel engelli ögrencim var. Tabi ki bireysel özellikleri farkl. Mesela kimi şarki söylemekten hoşlanırken, bir diğeri resim yapmaktan hoşlanıyor. Orta ă̆ır derecede zihinsel yetersizliği olan öğrencim diğerine nazaran daha yavaş ögrreniyor. Bu nedenle her bir ögrencimin seviyesine uygun çalışmalar planllyorum. Eleştirecek olursak, Ses Temelli Cümle Yönteminde okumayı ögrenirken, sorunlar olduğu için çözümler üretmek gerekiyor. Örneğin Ses Temelli Cümle Yöntemi dişında, tek tek sesleri okuma ve birleştirme uygulamaları denedim. Ayrıca heceleri tek tek yazdırıp, hece birleştirme yöntemini uyguladım. Bununla ilgili bir materyal gelişstirdim. Yapboz gibi, sesleri birleştirip, heceler oluşturuyorlar. Ayn heceleri eşleştirirken, farklı heceleri fark etmelerini sağllyorum, tıpkı bulmaca çözer gibi. Böylece ögrrenme sürecini oyunlaştırmaya çalışıyorum' (Ö7-E-35-11)

\section{sorunlar}

Zihinsel yetersizliği olan öğrencilere okuma-yazmayı öğretirken karşılaşılan

Okuma yazma öğretimi sırasında ne tür sorunlarla karşılaştıkları sorulduğunda öğretmenlerin genel olarak yöntem uygulamalarına bağlı olarak cevaplar verdikleri anlaşılmıştır. $\mathrm{Bu}$ çalışmada öğretmenlerin 'Ses Temelli Cümle Yöntemi'nin aşamalarını uygularken zihinsel yetersizliği olan öğrencilerin zorlandıklarını ifade ettikleri belirlenmiştir. Bu konuda öğretmenlerin tamamının sesi hissettirmede ve ses-hece-kelime gibi oluşumları birleştirmede sorunlar olduğuna dikkat çektiği; öğretmenlerin büyük bir çoğunluğunun da (Ö1, Ö4, Ö5, Ö6, Ö7, Ö8, Ö9, Ö12, Ö13) yazmada zihinsel yetersizliği olan çocukların sorunlarının olduğunu gözlemlediklerini belirttikleri anlaşılmıştır.

Zihinsel yetersizliği olan öğrencilere okuma-yazmanın öğretildiği süreçte, öğrenme güçlüğü yaşamalarına bağlı olarak; iletişim kurarken de sorunlar olduğuna değinen öğretmenler dışında (Ö2, Ö4, Ö6, Ö7, Ö12, Ö13), öğrencinin dikkatini toparlamada sorunlar olduğuna dikkat çeken öğretmenlerden (Ö2,Ö3, Ö4,Ö5, Ö6, Ö7, Ö8, Ö9, Ö11, Ö12) bazılarının ise öğretim süresinin yetmediğine (Ö3, Ö8, Ö9, Ö11, Ö12) işaret ettikleri ve dolayısıyla yöntemin basamaklarını uygularken tam olarak verim alamadıklarını belirttikleri tespit edilmiştir. Bu sonuçlar da gerek genel eğitim ve gerekse özel eğitim sınıfında görev yapan öğretmenlerin; zihinsel yetersizliği olan 
çocuklara okuma yazmayı öğretirken çocuğun iletişim sorunu ve dikkatini toparlama sorunu olması sebebiyle, öğretim süresinin yetmediğini, dolayısıyla da ses temelli cümle yönteminin basamaklarında verimli uygulamalar yapamadıklarını göstermektedir.

Aşağıda Şekil 3'de açıklayıcı görsel sunulduktan sonra, konu ile ilgili öğretmen ifadelerinden örnek alıntılar aktarılmıştır.

Şekil.3. Okuma-Yazmayı Öğretirken Karşılaşılan Sorunlar

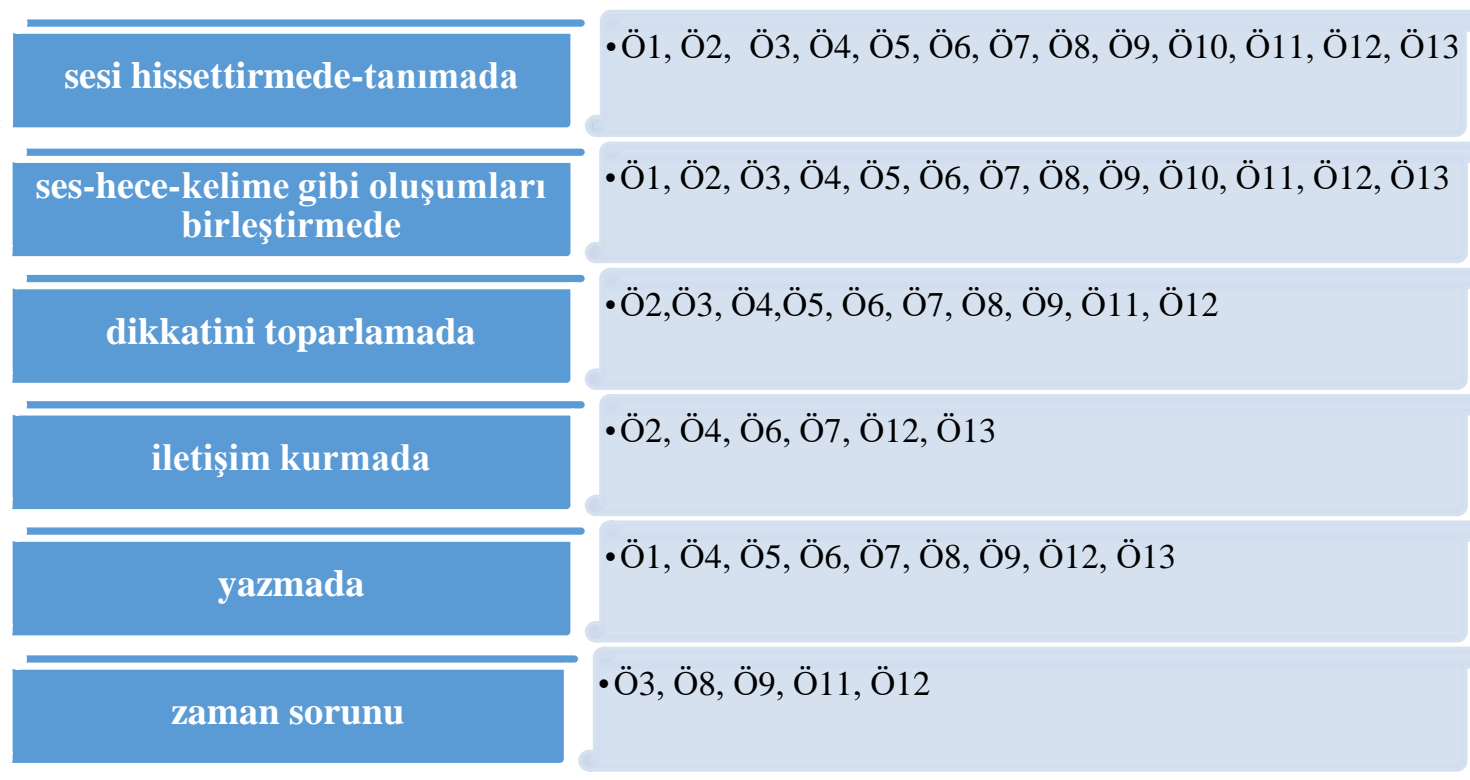

'En önemli karşılaştı̆̆ım sorun, bazı sesleri verirken ögrencinin karıştırması. Ses Temelli

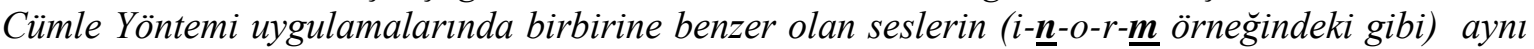
grupta peş peşe ögrretilmesi isteniyor. Böyle olunca öğrenci henüz $\underline{\boldsymbol{n}}$ - sesini ögrenmeden $\underline{\boldsymbol{m}}$ sesini ögrenmede güçlük çekiyor. Zihinsel yetersizliği olan ögrencimin genel olarak algilama sorunları olduğu için, okuma-yazmanın öğretildiği süreçte zamanla ilgili problemlerimiz oluyor. Diğer ögrrencilerle ilgilenirken, zaman açısından kaynaştırma öğrencisi için ek bir programı uygulamak oldukça güç.' (Ö3-E-40-16)

'Bireysel özellikleri gereği sesleri öğrenmede, hece oluşturmada sorunlar yaşıyorlar. Dikkatleri çabuk dağıllyyor. Öğrenemediklerinde sınıfinda dikkatini dağıtıyorlar. Yazıları çok güzel olamıyor. Büyük harfleri yazarken özellikle zorlanıyorlar. Yavaş yazdıkları için onları beklemek ve sürekli takip etmek gerekiyor. Sesleri ögrenirken, heceleri birleştirirken sorunlar oluyor. Ses Temelli Cümle yönteminin ses sirası bu çocuklara uygun değil.' (Ö4-E-38-13)

'Öğrenciler sesleri karlştırlyor. Özellikle birbirine benzeyen 'b ve $\underline{\boldsymbol{d}}$ ' gibi seslerini ayırt edemiyorlar. Ayrıca 'y ve $\breve{\underline{g}}$ ' seslerinin okunuşunda sorun oluyor bu sesleri ağız içinde oluştururken, güçlük çekiyorlar. Bu seslerle hece oluşturulduğunda, seslerin üzerine bask yapmayı denedim. Ancak çok bask yapılarak söylendiğinde bu kez de heceleri yanlı̧̧ telaffuz ettiklerini gözlemledim. Ayrıca Ses Temelli Cümle uygulamaların yaparken, seslerin sirası nedeniyle anlamsiz hecelere ulaşıllyor. Bu heceler çok soyut kaltyor. Daha anlaml yapılar elde edebilmek için, ses sırasını değiştirip, işlek heceleri ögretmeye çalışlyorum.' (Ö5-K-31-8)

'Öğrenciler parçadan bütüne yaklaşımında özellikle seslerin birleştirilmesinde zorluk yaşıyor. Örneğin, $\underline{\underline{t}}$ sesinin ögretiminde ögrenciye tu şeklinde sesi çıkarttırlyoruz. Hece oluşturmada ise $\underline{a}$ ile $\underline{\boldsymbol{t}}$ sesini birleştirildiğimizde, ögrenci bu kez at yerine atı diyor. Sesleri birleştirerek okumaya 
çalışırken bu kez okuma hızı da yavaş oluyor. Sesleri ayırt etme aşaması daha uzun zaman alıyor. Yazma aşamasında daha çok zaman ve ilgiye ihtiyaçları oluyor. Bu durum diğer öğrencilerimin slkilmalarına ve onlara ayırmam gereken zamanın da azalmasina neden oluyor.' (Ö8-E-41-7)

'Ses Temelli Cümle yöntemini uygulamaları sırasında en çok sılkıntı olan şey açık hece sorunu olmast sebebiyle, ögrencinin hece oluşumunu ögrenmesini zorlaştırtyor. Bu sorun 11 seste $(e, l, a, t, i, n, o, r, m, u, k)$ verildikten sonra, yavaş yavaş kalkmaya başliyor. Bu süreçte hece-kelime birleşimlerini kavramaları için çok tekrar yaptırmak gerekiyor.' (Ö11-E-36-14)

\section{Öğretmenlerin geliştirdikleri stratejiler}

Öğretmenlere okuma yazma öğretimi sırasında geliştirdikleri stratejiler sorulduğunda zihinsel yetersizliği olan öğrencilerin bireysel özellikleri sebebiyle algılama sorunları olduğundan, okuma-yazma sürecinde ilerleme düzeylerinin değişebildiğine dikkat çektikleri ve onlarla birebir ilgilenmenin önemli olduğuna inandıkları anlaşılmıştır. Öğretmenlerin tamamının sınıflarındaki zihinsel yetersizliği olan öğrencilerin özelliklerini gözlemleyerek, okuma-yazma çalışmalarında öğrencilerin kendi hızında öğrenmelerini kolaylaştırmaya özen gösterdikleri ve 'ses-hece-kelime' oluşumları çabuk unutulduğu için tekrar çalışmalarına çokça yer vermeye çalıştıkları tespit edilmiştir. Ayrıca 'farklı yöntemleri/uygulamaları deniyorum' diyen öğretmenlerin (Ö1, Ö3, Ö4, Ö5, Ö7, Ö8, Ö9, Ö10, Ö11) de çoğunlukta ( $\mathrm{f}=9$ ) olduğu anlaşılmıştır. Bunun dışında öğretmenlerin 'görsel-işitsel araçlar kullanıyorum.' (Ö1, Ö5, Ö6, Ö7, Ö8, Ö11, Ö12), 'dikte çalışmaları yaptırıyorum.' (Ö1, Ö3 Ö4, Ö7, Ö8) şeklinde stratejiler izledikleri anlaşılmıştır.

Özel eğitim sınıflarında farklı uygulamalara yer veren öğretmenlerden birisinin aynı zamanda (Ö1) 'renkli kalemlerle yazı yazdırıyorum.' şeklinde özel bir strateji geliştirdiği tespit edilmiştir. Genel eğitim sınıfinda görev yapan öğretmenlerden birisinin de (Ö3) 'ev ödevi veriyorum.' şeklinde verdiği cevapla okulda yapılan etkinliklerin devamlılı̆̆ını sağlamak için ev ödevi vererek veli desteği almaya çalıştığı anlaşılmıştır. Bu sonuçlar gerek genel eğitim ve gerekse özel eğitim sınıflarında görev yapan öğretmenlerin zihinsel yetersizliği olan çocuklara okuma yazma öğretirken 'ses-hece-kelime' oluşumunu öğretmek için, farklı uygulamaları denerken, çok tekrar yapmak zorunda kaldıklarına işaret etmektedir. Ayrıca görsel işitsel araçlar kullanarak, farklı uygulamalar deneyerek, dikte çalışmaları yaptırarak, renkli kalemlerle yazdırararak, okuma yazma öğretim sürecini anlaşılır hale getirmeye çalıştıklarını göstermektedir. Aşağıda Şekil 4'de açıklayıcı görsel sunulduktan sonra, öğretmenlerin geliştirdikleri stratejilere yönelik yaptıkları açıklamalarından örnek alıntılar aktarılmıştır. 
Şekil 4: Okuma-Yazma Öğretiminde Öğretmenlerin Geliştirdikleri Stratejiler

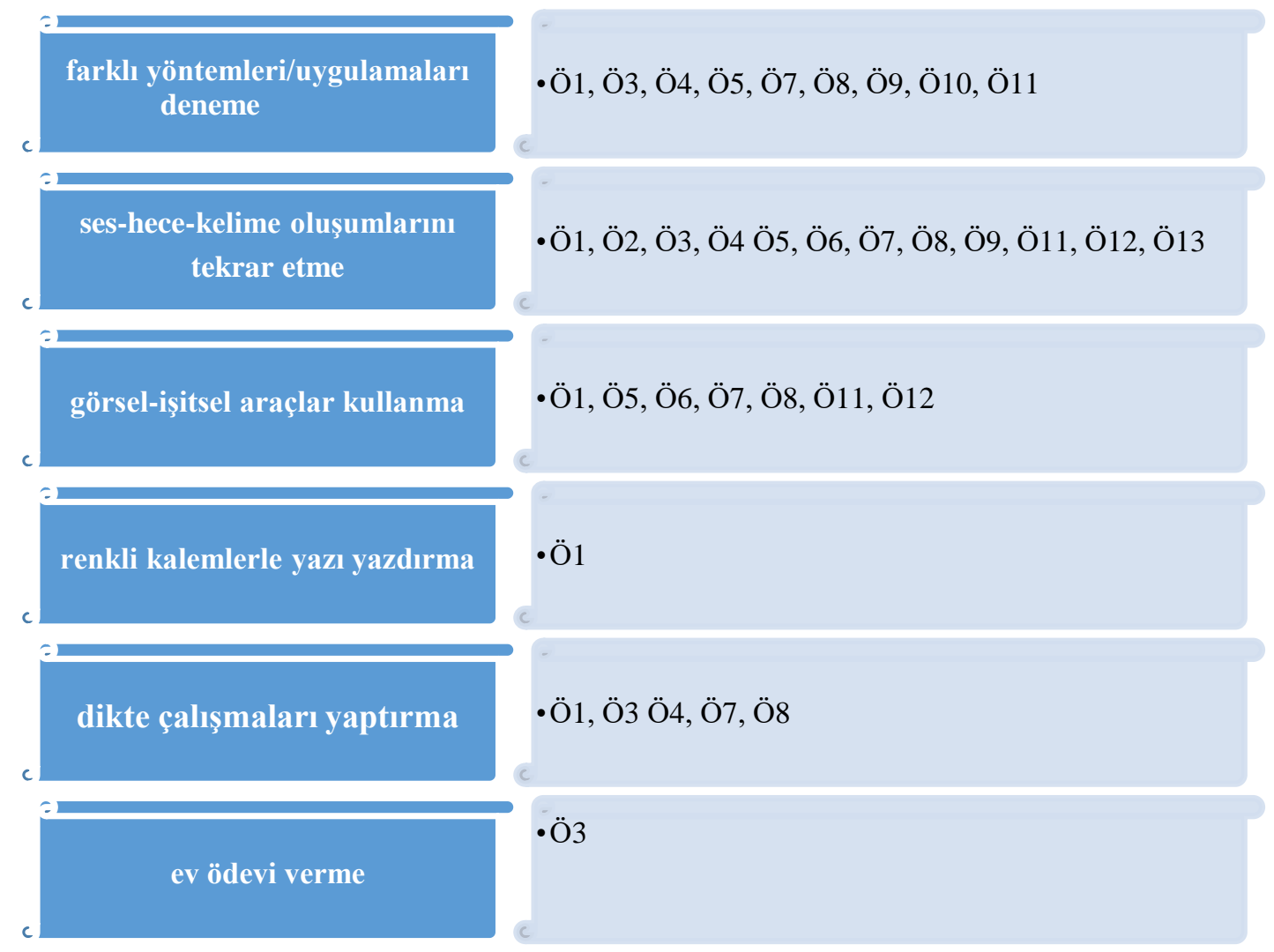

'Her ögrencinin hazır bulunuşluğu farklı oluyor. Algllama ve muhakeme etmede sorunlar sebebiyle zihinsel yetersizliği olan ögrencilerimizle Ses Temelli Cümle Yöntemini uygularken, araçgereç kullanmamı gerekiyor. Temel alışkanlıkları edindirebilmek için birebir ilgilenmemiz gerekiyor. Örneğin kalem tutma, serbest çizgi çalışmaları, düzenli çizgi çalışmaları yapılırken, ya da seslerin öğretimi gerçekleştirilirken, ögrencimi sürekli kontrol ediyorum ve dönüt veriyorum. Hedeflenen kazanımları tam anlamıyla ulaşamadıklarını gördüğümden, bol tekrarlara yer veriyorum. Seslerin öğretiminde özellikle sırasında değişikliklere gidiyorum. Bunun için denemeler yapıyorum, çocuk hangi sesi daha kolay ve önce öğreniyorsa, o sesle hece çalışmalarına geçiyorum. , (Ö4-E-38-13)

'Zihinsel yetersizliği olan öğrencilerimizin, algılama sorunları olduğu için okuma-yazma ögretimi tekrar üzerine yapılandırılmış durumdadır. Harf ve heceleri unutabiliyorlar. Normal ögrrencilerde ses bir veya 2 gün içinde ögretilirken, zihinsel yetersizliği olanlarda 1-2 hafta sürebiliyor. Hatta ögrenciye yeni bir ses öğrettiğinizde bir öncekini unuttuğunu görebiliyorsunuz. Öğrencinin dikkat süresi kısa olduğu için ve çok çabuk unuttuğu için, benim gibi ailenin de sesleri evde sürekli tekrar etmesini istiyorum. Benzer olan sesleri karıştırdiğg için, $\underline{\boldsymbol{n}}$ - ve $\underline{\boldsymbol{m}}$ gibi birbirine yakın seslerin öğretimini sonraya bıraktım. Sessiz harflere geçmeden, sesli harfleri ögretmeyi denedim.' (Ö3-E-40-16)

‘Öğrencilerim sesi kavramakta ve çıkarmada güçlükler çekiyorlar. Ayrıca hece ve kelimeler gibi yapıları oluşturmada zorlanıyorlar. Satır içinde yazı yazarken, zorlanan ögrencim, satır içine yazarken daha büyük yazıyor. Yazma çalı̧̧maları sırasında satır aralıklarını belirginleştirip, satır içine yazmaları konusunda sürekli uyarılar yapıyorum. Gerek işitsel ve gerekse görsel uyaranlar kullanarak, sesi daha iyi öğrenmelerine yönelik çalışmalar yapıyorum. Örneğin sesi CD’den 
dinletip, sesi resimli kartta gösterdikten sonra, ayna karşısında ağız içinde sesi oluşturmalarını istiyorum. Doğru olarak ses çıkarma, hece-kelime tanıma-oluşturma etkinliklerine yer verirken, benzerliklere ve farklılıklara dikkat çekiyorum, bol tekrar çalışmaları yaptırıyorum. Ses-hece-kelime gibi yapıları kavratırken, ayna karşısında 'ağız içinde' sesin nasıl oluştuğunu, seslerin bir araya gelerek hecelerin ve kelimelerin nasıl oluştuğunu uygulamal olarak gösteriyorum. Her iki ögrencimin de arkadaş kazanma ve iletişimi sürdürme sorunları var. Karşıllklı oynamayı bilmiyor. Bu nedenle iletişim becerilerini geliștirecek oyun gibi etkinliklere yer veriyorum.' (Ö6-K-36-6)

'Ses Temelli Cümle Yöntemi ile ögrrettiğim sesleri, ses kartlarlyla sık sık tekrar ediyorum. Sesleri duyabilmeleri için bilgisayardan görsel-işitsel ses-hece-kelime oluşumlarını gösterirken, sesi-heceyi-kelimeyi duymalarını sağllyorum. Ayrıca kartlara yazılı olan kelimeleri kalıp olarak okuturken, kalıp olarak ezberletmeye çalışıyorum. Okuma hızını artırabilmek için, sürekli olarak hece-kelime tekrarları dışında dikte çalışmaları yaptırıyorum.' (Ö8-E-41-7)

'Açık hecelerin öğrenilmesi zaman ald $\breve{g}$ v ve ses-hece oluşumlarının öğrenilmesi zor olduğu için, kendimce geliştirdiğim taktik şu: Açık hece ile ilgili kavram kartı hazırlayıp, sınıfin duvarına asıyorum. Açık hecelerin olduğu kartlara hatırlamayı kolaylaştırması için, resimler de ekliyorum. Mesela-ka hecesi için kardan adam -ke hecesi için kedi resmi, -te hecesi için terlik resmi ekleyip, kartı ögrencilere gösterip okutuyorum. Açı heceler elde edildikçe, sınıf duvarına astığımız kartları seçip, okuyoruz. Sesleri tekrar ederken, açık heceleri de kavram kartlarından gösterip, okutup, yazdirlyorum.' (Ö11-E-36-14)

\section{Öğretmenlerin geliştirdikleri öneriler}

Dördüncü temada ise öğretmenlerin zihinsel yetersizliği olan öğrencilere okuma-yazma öğretim etkinlikleri kapsamında geliştirdikleri öneriler değerlendirilmiştir. Buna göre öğrenme süreciyle ilgili olarak öğretmenlerin tamamı 'tekrarlara yer verilmeli', bazıları 'karma yöntemler kullan1lmalı' (Ö1, Ö3, Ö4, Ö5, Ö7, Ö8, Ö9) farklı araçlar kullanılmalı' (Ö1, Ö5, Ö6, Ö7, Ö8, Ö12), 'öğrencinin dikkati çekilmeli, ödüller verilip, motive edilmeli' (Ö2, Ö5, Ö7, Ö9, Ö10, Ö12, Ö13) şeklinde öneri geliştirdiği anlaşılmıştır. Bu sonuçlar da okuma yazma öğretim sürecinde zihinsel yetersizliği olan öğrenciler için tekrarın önemli önemli olduğu, karma yöntemlerin uygulanmasının bir çözüm olabileceği ve bu süreçte de öğrenciyi motive edecek uygulamalara yer verilmesinin uygun olacağını göstermektedir. Bunun dışında genel eğitim sınıfından iki (Ö3, Ö4) ve özel eğitim sınıfından da bir öğretmen (Ö5) olmak üzere toplam üç öğretmenin, 'Ses Temelli Cümle Yöntemi'nde grup seslerinin sırası değiştirilmeli' şeklinde öneri sunduğu; genel eğitim sınıfından iki (Ö2,Ö12) ve özel eğitim sınıfından bir öğretmenin (Ö6) de 'öğrenciyle iletişim kurulmalı' şeklinde sosyal becerilerin geliştirilmesine yönelik önerilerde bulunduğu anlaşılmıştır. Yine genel eğitim sınıfında görev yapan öğretmenlerden ikisinin (Ö3, Ö13) 'sınıfta/okulda yardımcı öğretmen olmalı' ve dördünün (Ö2, Ö3, Ö8, Ö9) 'zihinsel engelli öğrenci diğer öğrencilerden ayırmadan kaynaştırmalı' şeklinde öneri geliştirdiği tespit edilmiştir. Bu sonuçlar da genel eğitim sınıflarında zihinsel yetersizliği olan öğrencilerin akranlarıyla birlikte eğitim görmesine sıcak baktıkları ancak bazı durumlarda, sınıf öğretmenlerinin yardımcı öğretmene ihtiyaç duyduklarını göstermektedir. Aşağıda Şekil 5'de açıklayıcı görsel sunulduktan sonra, konu ile ilgili öğretmen ifadelerinden alıntılar aktarılmıştır. 
Şekil 5: Öğretmenlerin Geliştirdikleri Öneriler

karma yöntemler kullanılmalı

farklı araçlar kullanılmalı

diğer öğrencilerden ayırmadan kaynaştırmalı

dikkati çekilmeli/ödül verilip motive edilmeli

iletişim kurulmalı

tekrarlara yer verilmeli

ses sırası değiştirilmeli

sınıfta/okulda yardımeı öğretmen olmalı
• Ӧ1, Ö3, Ö4, Ö5, Ö7, Ö8, Ö9

•Ö1, Ö5, Ö6, Ö7, Ö8, Ö12

•Ö2, Ö3, Ö8, Ö9

•Ö2, Ö5, Ö7, Ö9, Ö10, Ö12, Ö13

•Ö2, Ö6, Ö12

•Ö1, Ö2, Ö3, Ö4, Ö5 Ö6, Ö7, Ö8, Ö9, Ö12, Ö13

• Ö3, Ö4, Ö5

•Ö3, Ö13

'Zihinsel yetersizliği olan ögrencilere başlangiçta 'Ses Temelli Cümle Yöntemi' uygulanabilir. Ancak, harf ve heceler de zaman zaman harmanlanarak okumalarl geliştirilebilir.' $(\ddot{O} 1-K-28-6)$

'Zihinsel yetersizliği olan öğrencilerin sınıf ortamına uyum să̆laması için, diğer öğrencilerden ayrı olduğunu hissettirmeden okuma-yazma faaliyetlerini yürütmeliyiz. Zihinsel yetersizliği olan öğrenciler ilgilenildiği takdirde bir süre sonra, diğer ögrencilerle kaynaşabiliyorlar. Bu süreçte uyum sağlamalarını kolaylaştırabilmek için, gerek ögretmen ve gerekse arkadaşlarıyla iletişim kurması sağlanırken tüm etkinliklere katılımı sağlanmalı ve sınıf ortaminda olup-bitenlerle ilgilenmesi için sürekli dikkati çekilmelidir.' (Ö2-K-49-25)

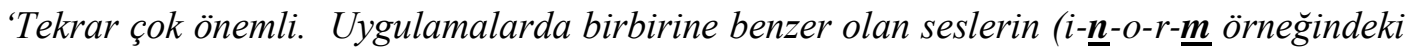
gibi) birbirine karıştırlmamast için, grupların yeniden oluşturulması gerekir. Ayrıca sesli harfler (a-e,l-i-o-ö-u-ü) öncelikle verildikten sonra, grup sesleri ögretilmeli. Zihinsel yetersizliği olan ögrenciyle birebir ilgilenmek gerekiyor, ancak müstakil sinfflarda diğer öğrencilerimiz de olduğundan, zamant yetiştiremiyor, onunla yeterince ilgilenemediğimizi düşünüyorum. Bu nedenle, her okulun zihinsel engelli ögrretmeni olmall. Sinıfimızda zihinsel yetersizliği olan ögrrencimiz olduğunda, zihinsel yetersizliği olanlar ögretmeni bize yardımcı olmalı, birlikte koordineli olacak şekilde çalı̧̧abiliriz.' (Ö3-E-40-16)

'Ses Temelli Cümle Yöntemi ile bireşim çalışmalarında zorlanıyorlar. Bu sebepten, ses tekrarları verirken, kelimeleri kalıp olarak ögretiyorum. Ses-Kelime gibi karma uygulamalara ne zaman ihtiyaç duyulduğuna ögretmenin gözlem yaptıktan sonra karar vermesi gerektiğini düşünüyorum.' (Ö8-E-41-7)

'Ses Temelli Cümle Yöntemi ile üç grup seslerini verdikten sonra, tek tek sesleri tekrar ediyorum. Bu arada, hece çalı̧̧maları yaptırıyorum. Okuması mümkün gözükmeyen ögrenci de dahi 
hece yönteminin devreye girmesi yararl oluyor. Bu yüzden öğretmenlere ses-hece yöntemine başvurarak karma yöntem uygulamalarını tavsiye ediyorum' (Ö9-K-30-9)

'Sesleri sürekli unutuyor, her gün tekrar çalışmaları yaptırlyoruz. Öğrencinin bir günü bir gününü tutmuyor. Bu gün çok iyi ise, yarın öbür gün hiçbir şeyi hatırlamayabiliyor. Birleştirme aşaması işimiz daha güç. Bu aşamada, -el, -al gibi kapalı heceleri okuyup, yazmaları kolay, fakat le, -la gibi açı heceleri okumaları ve birleştirebilmeleri 1 yıl sürüyor. Ama sabrettiğiniz zaman oluyor, tekrarlar etkili oluyor, en mutlu anımızda tabii ki o anlar. Sesler sürekli verilmeli ve hece oluşumlarını bıkmadan sürekli tekrar edilmeli o yüzden.' (Ö12-E-33-11)

\section{Sonuç Tartışma ve Öneriler}

2005-2006 öğretim yılından itibaren ülkemizde uygulamaya konulan Ses Temelli Cümle Yöntemi ile ilkokuma yazmanın öğretimine seslerle başlanmakta, anlamlı bütün oluşturacak birkaç ses verildikten sonra seslerden, hecelere, kelimelere ve cümlelere ulaşılmaktadır. Yöntemin olumlu yanlarına vurgu yapılarak ve Türkçe'nin dil yapısına uygun olduğuna işaret edilerek bu yöntem ile kısa sürede okuma ve yazmanın öğretilebileceği (Ferah, 2009; Güneş, 2005) ileri sürülmektedir. Ancak zihinsel yetersizliği olan çocuklar akranlarına göre bireysel açıdan farklılıklar gösterdiklerinden, farklı duygusal özelliklere, bilişsel açıdan ise farklı öğrenme stillerine/öğrenme özelliklerine/öğrenme hızına sahip olduklarından yaşıtlarına uygun olduğu ileri sürülen yöntemler dışında farklı uygulamalara ihtiyaç duyabilmektedir (Deniz, 2008; Döngel, 2009; Şengül ve Akçin, 2010).

$\mathrm{Bu}$ çalışmada genel ve özel eğitim sınıflarında zihinsel yetersizliği olan öğrencilere okuma yazmayı öğretirken karşılaşılan sorunların çözümünde geliştirdikleri stratejileri belirleyebilmek için ilkokulda görev yapan öğretmenlerin görüşlerine başvurulmuştur. Araştırma bulguları 'öğretmenlerin okuma-yazma öğretim sürecinde gerçekleştirdikleri faaliyetler, karşılaştıkları sorunlar, uyguladıkları stratejiler ve geliştirdikleri öneriler' olmak üzere dört temada değerlendirilmiştir.

Zihinsel yetersizliği olan bireylerin bilişsel gelişim süreçlerini inceleyen bazı araştırmacılar bireysel özellikleri gereği akademik yeterlilikler yönünden akranlarından anlamlı farklılık gösterebildiğine (Mastropieri ve Scruggs, 2016; Özkan, Öncül ve Kaya, 2013) dikkat çekmektedir. Bazı araştırmacılar da zihinsel yetersizliği olan çocukların öğrenme hızının yavaş olduğunu bazı becerileri yaşıtlarından daha yavaş öğrendiklerine dikkat çekmektedir (Eripek, 1998; Katims, 1996; Kırcali-İftar ve Uysal, 1999; Mascolo-Glosser, 2015; Villanueva vd., 2012). Bu nedenle zihinsel yetersizliği olan öğrencilerin olduğu sınıflarda öğretmenlerin, öğrenci ihtiyaçlarını göz önünde bulundurarak yöntem seçiminde, araç-gereç kullanımı ve öğretim ortamının düzenlenmesinde bazı özel uyarlamalara gitmeleri gerekmektedir.

$\mathrm{Bu}$ çalışmada öğretmenlerin okuma yazma öğretim sürecinde gerçekleştirdikleri faaliyetlere bakıldığında, öğretmenlerin tamamının, öğrenci merkezli bir yaklaşım benimseyerek okuma-yazma etkinliklerini zihinsel yetersizliği olan öğrencinin gereksinimlerini göz önünde bulunduracak şekilde gerçekleştirdikleri anlaşılmıştır. Öğretmenlerin çocuğu merkeze alan anlayışla öğrenme sürecinde öğrenci ihtiyaçlarını karşılamaya özen gösterdikleri tespit edilmiştir. Okuma yazma etkinlikleri sırasında öğrencinin yetersizliklerine değil, yeterliliklerine odaklanmaya önem verdikleri bu amaç için ise okuma-yazma öğretiminde 'yöntemleri seçerken, araç-gereçleri kullanırken, etkinlikleri düzenlerken' farklı uygulamalara da yer vermeye çalıştıkları anlaşılmıştır.

Öğretmenlerin yöntem konusunda ne tip uyarlamalar yaptığına bakıldığında, öğretmenlerin tamamının 'Ses Temelli Cümle Yöntemi'ni kullandıkları anlaşılmıştır. Ancak altı öğretmenin (Ö1, Ö5, Ö7, Ö9, Ö10, Ö11) ‘Ses Temelli Cümle Yöntemi’ne ek; ‘Ses ve Hece Yöntemi’ni kullandığ1 
anlaşılmıştır. Genel eğitim sınıflarında görev yapan öğretmenlerden üçü (Ö9, Ö10, Ö11) 'Ses ve Hece yöntemi bir arada kullanarak hafif düzeyde zihinsel yetersizliği olan birer öğrenciye okuma yazmayı öğretmeye çalışmaktadır. Yine genel eğitim sınıfında görev yapan bir sınıf öğretmen de (Ö8) 'Ses Temelli Cümle Yöntemi' ile beraber 'Ses ve Kelime Yöntemi'ni bir arada harmanlayarak karma yöntem uygulamalarına yer vererek hafif düzeyde zihinsel yetersizliği olan bir öğrencisine okuma yazmayı öğretmeye çalıştığı anlaşılmıştır. Özel eğitim sınıfında görev yapan öğretmenlerden birinin (Ö1) ağır derecede zihinsel yetersizliği olan bir öğrenciye; bir öğretmenin (Ö5) dördü hafif ve birer de orta ve ağır olmak altı öğrenciye; bir diğer öğretmenin de (Ö7) hafif derecede iki ve orta ağır derecede zihinsel yetersizliği olan bir olmak üzere üç öğrenciye 'Ses ve Hece' yöntemlerini harmanlayarak okuma yazmayı öğretmeye çalıştığı tespit edilmiştir. Bu sonuçlar özel eğitim ve genel eğitim sınıflarında ikinci bir yöntem olarak daha çok 'Ses ve Hece'; yine genel eğitim sınıfinda 'Ses ve Kelime' yöntemlerinin bir arada üçüncü bir yöntem olarak kullanıldığını ve yöntem konusunda özel uyarlamalar yapıldığını göstermektedir.

Öğretim ortamının düzenlenirken öğrenmeyi kolaylaştırıcı görsel ve işitsel mesajlar içeren araçların kullanılması farklı ihtiyaçları olan çocukların ihtiyaçlarının karşılanması önemlidir (Demirel, 2004). Farklı gereksinimleri olan özel gereksinimli çocuklar eğitim ortamlarında farklı deneyimlere ve öğretimsel uyarlamalara gereksinim duymaktadırlar (Yıldırım ve Albuz, 2010). Bu nedenle özellikle öğrenme hızı ve öğrenme süreçleri yaşıtlarından farklı olan öğrencilerin bulunduğu sınıflarda eğitim ortamının zenginleşmesini sağlayacak ve öğrencilerin öğrenmelerini kolaylaştıracak uygun ders araç gereçlerinin seçilip, kullanılması ve öğrencilerin bireysel ihtiyaçların karşılanması gerekmektedir (Başboğaoğlu, 2009). Özellikle okuma yazma etkinlikleri sırasında zihinsel yetersizliği olan öğrenciler için yazılı, görsel ve sesli materyallerin bir arada kullanılmasının öğrenmeyi kolaylaştırıcı etkisi olduğu ileri sürülmektedir (Shaywits, 2003). Bu noktada öğretmenlerin zihinsel yetersizliği olan öğrencilerin olduğu sıniflarda öğretmenlerin ne tür araçgereçler kullandıklarının incelenmesi, öğretim ortamının zenginleştirilmesi açısından yararlı olabilir.

$\mathrm{Bu}$ çalışmada öğretmenlerin okuma-yazma öğretiminde araç-gereç kullanmanın önemli olduğuna işaret ettikleri belirlenmiştir. Zihinsel engelliler öğretmenleriyle yaptığı çalışmasında da benzer şekilde Avcıoğlu (2012), öğretmenlerin görsel açıdan eğitimi desteklemesi, konuları somutlaştırması, öğrencilerin dikkatlerini çektiği ve öğrenmeyi eğlenceli hale getirdiği için araçgereç kullanmanın gerekli olduğu bulgusuyla örtüşmektedir. Bu çalışma gerek genel eğitim sınıfı öğretmenleri ve gerekse özel eğitim sınıfi öğretmenlerinden kullandıkları araç-gereçlere örnek vermeleri istendiğinde; genel eğitim sınıfından bir (Ö3) ve özel eğitim sınıfından bir öğretmenin (Ö5) MEB tarafından önerilen kılavuz kitabı kullandıklarını belirttikleri anlaşılmıştır. Genel eğitim sınıfında görev yapan öğretmenin (Ö3) hafif düzeyde zihinsel yetersizliği olan bir öğrencisi, özel eğitim sınıfinda görev yapan öğretmenin ise (Ö5) hafif, orta ve ağır derecede zihinsel yetersizliği olan altı öğrencisi bulunmaktadır. Özel eğitim sınıfında görev yapan bir öğretmenin de sınıfında bulunan ağır derecede zihinsel yetersizliği olan öğrencisi için 'Özel Çocuklar İçin Resimlerle Okuyorum' (Ö1) kitabını izlediği anlaşılmıştır. Farklı araç-gereç kullanmanın önemine değinen özel eğitim öğretmenlerinden ikisinin de (Ö1 ve Ö6) yerine göre 'hareketli resimleri', ikisinin (Ö1,Ö6) 'resimli kartları, üçünün (Ö5, Ö6, Ö7) ve 'öğretmen yapımı görsel materyalleri' ikisinin (Ö5, Ö6) bilgisayardan yararlandığı anlaşılmıştır. Buna karşılık genel eğitim sınıfından üç öğretmenin (Ö8, Ö11, Ö12) bilgisayarı ve sadece bir öğretmenin (Ö9) öğretmen yapımı görsel materyalleri kullandıkları belirlenmiştir. Bu sonuçlar da genel eğitim sınıfında görev yapan öğretmenlere kıyasla özel eğitim öğretmenlerinin farklı araçları kullanma konusuna daha fazla önem verdiklerini ortaya koymaktadır. 
Öğretmenlere ne tür etkinliklere yer verdikleri sorulduğunda ise bazı öğretmenlerin zihinsel yetersizliği olan öğrencilerin dikkatlerini çekmek ve 'Ses Temelli Cümle Yöntemi'nin uygulama aşamalarında öğrencilerin öğrenmesini kolaylaştırabilmek amacıyla farklı etkinliklere yer vermeye çalıştıkları anlaşılmıştır. Bu öğretmenlerden birinin öğretmenin (Ö1), 'eğlenceli etkinliklere', ikisinin (Ö1, Ö6) 'oyunlara' ve beşinin de (Ö1, Ö7, Ö10, Ö11, Ö12) 'eğitici oyunlara' yer verdikleri anlaşılmıştır. Bu sonuçlar da genel eğitim sınıfında görev yapan öğretmenlerden sadece ikisinin (Ö10, Ö11) eğitici oyunlara yer verdiklerini; buna karş1lık özel eğitim sınıfında görev yapan öğretmenlerin 'oyunlar, eğitici oyunlar, eğlenceli etkinlikler gibi farklı etkinliklere yer vererek öğrenme sürecini eğlenceli hale getirmeye çalıştıklarını göstermektedir. Benzer şekilde Yıkmış, Terzioğlu, Kot ve Aktaş (2017) özel eğitim öğretmenlerinin, okuma-yazma öğretiminde öğretimini kolaylaştırmak, kalıcılı̆̆ sağlamak, ipucu olarak kullanmak ve öğrenmeyi hızlandırmak için oyunlardan yararlandıkları sonucuna ulaşmışlardır. Şengül (2008) özel eğitim öğretmenlerinin okuma yazma öğretim sürecinde olay ve eşleme kartları, ilk okuma yazma kitapları, hece kitaplarını kullandıklarını, ayrıca eşleme ve kelime kartlarıyla etkinlikler yaparken süreci oyunlaştırdıklarını ortaya koymuştur.

Okuma yazma öğretimi sırasında ne tür sorunlarla karşılaştıkları sorulduğunda öğretmenlerin genel olarak yöntem uygulamalarına bağlı olarak cevaplar verdikleri anlaşılmıştır. $\mathrm{Bu}$ çalışmada öğretmenlerin 'Ses Temelli Cümle Yöntemi'nin aşamalarını uygularken zihinsel yetersizliği olan öğrencilerin zorlandıklarını ifade ettikleri belirlenmiştir. Bu konuda öğretmenlerin tamamının sesi hissettirmede ve ses-hece-kelime gibi oluşumları birleştirmede sorunlar olduğuna dikkat çektiği; öğretmenlerin büyük bir çoğunluğunun da ( $\mathrm{f}=9$ ) yazmada zihinsel yetersizliği olan çocukların sorunlarının olduğunu gözlemlediklerini belirttikleri anlaşılmıştır.

Zihinsel yetersizliği olan öğrencilere okuma-yazmanın öğretildiği süreçte, öğrenme güçlüğü yaşamalarına bağlı olarak; iletişim kurarken de sorunlar olduğuna değinen öğretmenler dışında ( $\mathrm{f}=6$ ), öğrencinin dikkatini toparlamada sorunlar olduğuna dikkat çeken öğretmenlerden $(f=10)$ bazılarının ise öğretim süresinin yetmediğine $(f=5)$ işaret ettikleri ve dolayısıyla yöntemin basamaklarını uygularken tam olarak verim alamadıklarını belirttikleri tespit edilmiştir. Bu sonuçlar da gerek genel eğitim ve gerekse özel eğitim sınıfında görev yapan öğretmenlerin; zihinsel yetersizliği olan çocuklara okuma yazmayı öğretirken çocuğun iletişim sorunu ve dikkatini toparlama sorunu olması sebebiyle, öğretim süresinin yetmediğini, dolayısıyla da ses temelli cümle yönteminin basamaklarında verimli uygulamalar yapamadıklarını göstermektedir.

Karaca (2018) araştırmasında zihinsel yetersizliği olan öğrencilere okuma becerileri kazandırırken öğretmenlerin çeşitli gücüklerle karşılaştıklarını ve bu güçlüklerin öğrencilerin okumaya yönelik motivasyon ve dikkat eksikliğinden kaynaklandığını ileri sürmüştür. Ses temelli cümle yönteminin basamaklarında da bazı öğrencilerin harflerden hece, hecelerden kelime oluşturma aşamalarında sorunlar yaşadıklarını ve okuduğunu anlama sorunlarının olduğunu ortaya koymuştur. $\mathrm{Bu}$ nedenle zihinsel engelli öğrenciler için ses temelli cümle yönteminin yeterli olmadığını ve bu çocuklar için farklı yöntem ve tekniklerden yararlanılması gerektiğine işaret etmiştir. Benzer şekilde okuduğunu anlama sorunlarına dikkat çeken, Tokta ve Avcıoğlu (2012) bazı öğretmenlerin ses temelli cümle yönteminin zihinsel yetersizliği olan öğrencilere uygun olmadığını belirttiklerini ortaya koymuştur.

Buğday (2015) zihinsel yetersizliği olan öğrencilerin okuma yazma öğretim sürecinde zorlandıklarını; okumayı geç öğrendiklerini ses temelli işlem basamaklarında 'ses, hece, kelime ve cümleleri’ okuma sorunlarının 1. gruptan 6. gruba doğru gidildikçe arttığını tespit etmiştir. Arabacı 
(2009), zihinsel yetersizliği olan öğrencilerin farklı zihinsel özelliklere sahip olduğunu ancak, bu çocuklar için hazırlanmış okuma-yazma ve diğer ders kitaplar ve ortak bir teknik olmaması nedeniyle öğretmenlerin özel eğitim sınıf öğretmenlerinin zihinsel yetersizliği olan öğrenciler için farklı teknikler kullandıklarını belirtmiştir. Şengül (2008), özel eğitim öğretmenleriyle yaptığ1 araştırmasında, öğrencilerin okuma yazma sürecinde zorlandıklarını bu nedenle de ses yöntemi ile cümle çözümleme yöntemini bir arada kullandıklarını ortaya koymuştur. Öğretmenlerin çoğunun gözlem yaparak, öğrencilerin bireysel çalışma kağıtlarını inceleyerek ve ölçüt bağımlı testleri kullanarak okuma yazma öğretiminde gelişim sürecini değerlendirdiklerini ortaya koymuştur.

$\mathrm{Bu}$ çalışmada öğretmenlere okuma yazma öğretimi sırasında geliştirdikleri stratejiler sorulduğunda zihinsel yetersizliği olan öğrencilerin bireysel özellikleri sebebiyle algılama sorunları olduğundan, okuma-yazma sürecinde ilerleme düzeylerinin değişebildiğine dikkat çektikleri ve onlarla birebir ilgilenmenin önemli olduğuna inandıkları anlaşılmıştır. Öğretmenlerin tamamının sınıflarındaki zihinsel yetersizliği olan öğrencilerin özelliklerini gözlemleyerek, okuma-yazma çalışmalarında öğrencilerin kendi hızında öğrenmelerini kolaylaştırmaya özen gösterdikleri ve 'seshece-kelime' oluşumları çabuk unutulduğu için tekrar çalışmalarına çokça yer vermeye çalıştıkları tespit edilmiştir. Ayrıca 'farklı yöntemleri/uygulamaları deniyorum' diyen öğretmenlerin (Ö1, Ö3, Ö4, Ö5, Ö7, Ö8, Ö9, Ö10, Ö11) de çoğunlukta (f=9) olduğu anlaş1lmıştır. Bunun dışında öğretmenlerin 'görsel-işitsel araçlar kullanıyorum.' (Ö1, Ö5, Ö6, Ö7, Ö8, Ö11, Ö12), ‘dikte çalışmaları yaptırıyorum.' (Ö1, Ö3 Ö4, Ö7, Ö8) şeklinde stratejiler izledikleri anlaşılmıştır. Özel eğitim sınıflarında farklı uygulamalara yer veren öğretmenlerden birisinin aynı zamanda (Ö1) 'renkli kalemlerle yazı yazdırıyorum.' şeklinde özel bir strateji geliştirdiği tespit edilmiştir. Genel eğitim sınıfında görev yapan öğretmenlerden birisinin de (Ö3) 'ev ödevi veriyorum.' şeklinde verdiği cevapla okulda yapılan etkinliklerin devamlılığını sağlamak için ev ödevi vererek veli desteği almaya çalıştığı anlaşılmıştır. Bu sonuçlar gerek genel eğitim ve gerekse özel eğitim sınıflarında görev yapan öğretmenlerin zihinsel yetersizliği olan çocuklara okuma yazma öğretirken 'ses-hece-kelime' oluşumunu öğretmek için, farklı uygulamaları denerken, çok tekrar yapmak zorunda kaldıklarına işaret etmektedir. Ayrıca görsel işitsel araçlar kullanarak, farklı uygulamalar deneyerek, dikte çalışmaları yaptırarak, renkli kalemlerle yazdırararak, okuma yazma öğretim sürecini anlaşılır hale getirmeye çalıştıklarını göstermektedir.

Dördüncü temada ise öğretmenlerin zihinsel yetersizliği olan öğrencilere okuma-yazma öğretim etkinlikleri kapsamında geliştirdikleri öneriler değerlendirilmiştir. Buna göre öğrenme süreciyle ilgili olarak öğretmenlerin tamamı 'tekrarlara yer verilmeli', bazıları 'karma yöntemler kullanılmal1' (Ö1, Ö3, Ö4, Ö5, Ö7, Ö8, Ö9) farkl1 araçlar kullanılmal1' (Ö1, Ö5, Ö6, Ö7, Ö8, Ö12)), 'öğrencinin dikkati çekilmeli, ödüller verilip, motive edilmeli' (Ö2, Ö5, Ö7, Ö9, Ö10, Ö12, Ö13) şeklinde öneri geliştirdiği anlaşılmıştır. Bu sonuçlar da okuma yazma öğretim sürecinde zihinsel yetersizliği olan öğrenciler için tekrarın önemli önemli olduğu, karma yöntemlerin uygulanmasının bir çözüm olabileceği ve bu süreçte de öğrenciyi motive edecek uygulamalara yer verilmesinin uygun olacağını göstermektedir. Bunun dişında genel eğitim sınıfından iki (Ö3, Ö4) ve özel eğitim sınıfından da bir öğretmen (Ö5) olmak üzere toplam üç öğretmenin, 'Ses Temelli Cümle Yöntemi'nde grup seslerinin sırası değiştirilmeli' şeklinde öneri sunduğu; genel eğitim sınıfından iki (Ö2,Ö12) ve özel eğitim sınıfından bir öğretmenin (Ö6) de 'öğrenciyle iletişim kurulmalı' ş̧eklinde sosyal becerilerin geliştirilmesine yönelik önerilerde bulunduğu anlaşılmıştır. Yine genel eğitim sınıfında görev yapan öğretmenlerden ikisinin (Ö3, Ö13) 'sınıfta/okulda yardımcı öğretmen olmalı' ve dördünün (Ö2, Ö3, Ö8, Ö9) 'zihinsel yetersizliği olan öğrenci diğer öğrencilerden ayırmadan kaynaştırmalı’ şeklinde öneri geliştirdiği tespit edilmiştir. Bu sonuçlar da genel eğitim sınıflarında 
zihinsel yetersizliği olan öğrencilerin akranlarıyla birlikte eğitim görmesine sıcak baktıkları ancak bazı durumlarda, sınıf öğretmenlerinin yardımcı öğretmene ihtiyaç duyduklarını göstermektedir.

$\mathrm{Bu}$ araştırma sonuçları gerek genel eğitim ve gerekse özel eğitim sınıfında görev yapan öğretmenlerin; zihinsel yetersizliği olan çocuklara okuma yazmayı öğretirken çocuğun iletişim sorunu ve dikkatini toparlama sorunu olması sebebiyle, öğretim süresinin yetmediğini, dolayısıyla da ses temelli cümle yönteminin basamaklarında verimli uygulamalar yapamadıklarını göstermektedir. Ayrıca zihinsel yetersizliği olan çocuklara okuma yazma öğretirken 'ses-hecekelime' oluşumunu öğretmek için farklı uygulamaları denedikleri, fazla tekrar yapmak zorunda kaldıkları, görsel işitsel araçlar kullanarak, farklı uygulamalar deneyerek, dikte çalışmaları yaptırarak, renkli kalemlerle yazdırarak, okuma yazma öğretim sürecini anlaşılır hale getirmeye çalıştıkları anlaşılmaktadır. Bazı öğretmenlerin ise Ses Temelli Cümle Yöntemini uygularken 'SesHece, Ses-Kelime' gibi yöntemleri bir arada harmanladıkları ve karma yöntemlerin kullanılması yönünde öneriler geliştirdikleri görülmektedir. Bu sonuçlar da okuma yazma öğretim sürecinde zihinsel yetersizliği olan öğrenciler için tekrarın önemli olduğu, karma yöntemlerin uygulanmasının bir çözüm olabileceği ve bu süreçte de öğrenciyi motive edecek uygulamalara yer verilmesinin uygun olacă̆ını göstermektedir.

Okuma-yazma etkinliklerinde öğretmenlere düşen görev yaşıtlarına göre yavaş ya da güç öğrenen zihinsel yetersizliği olan öğrencilerin özelliklerini göz önünde bulundurmak ve toplumsal yaşama uyum sağlaması için zihinsel yetersizliği olan öğrencinin performans düzeyini sürekli olarak dikkate alarak okuma-yazma gibi ihtiyacı olan temel bilgi ve becerileri kazandırmaktır. Bu süreçte yaşıtlarından farklı özellikler gösteren ve bilişsel açıdan yetersizlikleri olan zihinsel yetersizliği olan çocuklara farklı öğrenme firsatlarının sunulması ve öğretim çevresinin zenginleştirmesi gerekmektedir. Bu noktada öğretmenin zihinsel yetersizliği olan özelliklerini de göz önünde bulundurarak öğrenme sürecinde uyarlamalar yapması, uygun araç-gereçler kullanması, gerektiğinde öğretimde yöntem değişikliğine gitmesi önerilebilir. Bu çalışmada genel eğitim sınıfında ve özel eğitim öğretmenlerin görüşleri incelenerek, meslekte bilgi ve deneyimlerine bağlı olarak okuma yazma öğretim sürecinde geliştirdikleri stratejiler belirlenmeye çalışılmıştır. Bu açıdan araştırmada elde edilen sınıfında zihinsel yetersizliği olan öğrencileri bulunan öğretmelere ne tür uygulamalara yer verilebileceği ve ne tür stratejilerin işe yarayabileceği konusunda yol gösterici olabilir.

$\mathrm{Bu}$ araştırmada elde edilen bulgular zihinsel yetersizliği olan öğrencilerin okuma yazma öğretim sürecinde ne tür güçlüklerle karşılaştıklarını da göstermektedir. Farklı örneklem gruplarıyla yapılacak çalışmalarla ise zihinsel yetersizliği olan öğrencilerle okuma-yazma etkinliklerinin nasıl uygulandığı ve ne tür uygulamalardan olumlu sonuçlar alındığı ortaya konulabilir. Ayrıca okumayazma öğretiminde öğretmenlerin geliştirip/uyguladıkları yöntemler ya da farklı uygulamalar varsa araştırılarak (nicel-deneysel ya da nitel araştırma- eylem araştırmaları, tek denekli desenli nitel araştırmalar gibi) sonuçların değerlendirilmesi yararlı olabilir. Bu sonuçlar da zihinsel yetersizliği olan öğrenciler için okuma-yazma yöntemlerinin geliştirilip/denenmesi ve yeni yöntemlerin literatüre kazandırılması anlamında etkili olabilir.

\section{Kaynakça}

Aker, Z. (2009). Zihinsel engelli öğrencilere okuma-yazma öğretiminde kullanilan ses temelli cümle yöntemi ile cümle yönteminin etkililiğine ilişkin öğretmen görüşlerinin belirlenmesi (Yayımlanmamış yüksek lisans tezi). Abant İzzet Baysal Üniversitesi, Sosyal Bilimler Enstitüsü, Bolu. 
Akyol, H. (1997). Öğrenme güçlüğü olan çocuklara okuma yazma öğretimi. Milli Eğitim Dergisi, $136,16-19$.

Arabacı, İ. E. (2009). Özel eğitim sinıflarında görev yapan sinıf ögrretmenlerinin eğitilebilir zihin engelli ögrencilere ilkokuma öğretiminde kullanılan yöntem ve tekniklere ilişkin görüşlerinin değerlendirilmesi (Yayınlanmamış yüksek lisans tezi). Selçuk Üniversitesi Sosyal Bilimler Enstitüsü, Konya.

Armutçu-Arslan, O. (2008) Zihinsel yetersizlikten etkilenmiş ögrencilere word belgesi üzerine yazı yazma becerisinin kazandırılmasında eşzamanlı ipucu işlem süreci ile yapılan ögretimin etkililiği (Yayınlanmamış yüksek lisans tezi). Gazi Üniversitesi Eğitim Bilimleri Enstitüsü, Ankara.

Aral, N. ve Gürsoy, F. (2007). Özel eğitim gerektiren çocuklar. İstanbul Morpa Kültür Yayınları Ltd. Şti.

Avcıoğlu, H. (2012). Zihin engelliler sınıf öğretmenlerinin araç-gereç kullanımına ilişkin görüşleri International Journal of New Trends in Arts, Sports \& Science Education, 1(2), 118-133

Başal, M. ve Batu, S. E. (2002). Zihin özürlü öğrencilere okuma yazma öğretme konusunda alt özel sınıf öğretmenlerinin görüss ve önerileri. Özel Eğitim Dergisi, 3 (2), 85-97.

Başboğaoğlu, U. (2009). Öğretim teknolojileri ve materyal tasarımı. Ö. Demirel ve E. Altun, (Eds.), Öğretim sürecinde kullanılan araçlar ve görsel-işitsel araçlar. (67-85). Ankara: Pegem Akademi.

Buğday, M. (2015). Okula devam eden zihinsel yetersizliği olan öğrencilerin okuma yazma beceri düzeylerinin belirlenmesi (Yayınlanmamış Yüksek Lisans Tezi). Necmettin Erbakan Üniversitesi Eğitim Bilimleri Enstitüsü. Konya

Demirel, Ö. (2004). Türkçe ve sınıf ögrretmenleri için Türkçe öğretimi. Ankara: Pegem Yayıncıllk.

Creswell, J. (2012). Nitel araştırma yöntemleri. Gözden Geçirilmiş 2. Bask1, (Çev. M. Bütün ve S. B. Demir. Ankara: Siyasal Kitabevi

Creswell, J. (2013). Nitel ve nicel ve karma yöntem yaklaşımları araştırma deseni. 4. Baskıdan Çeviri (Çev. Edit: S. B. Demir ), Ankara: Eğiten Kitap

Çelenk, S. (2005). İlk okuma yazma programı ve öğretimi. Ankara: Anı Yayıncılık.

Deniz, S. (2008).Özel eğitim sinıfina devam eden zihin engelli ögrencilere okuma-yazma öğretiminde kullanılan ögretim yöntemlerine yönelik öğretmen görüşlerinin değerlendirilmesi (Yayınlanmamış yüksek lisans tezi). Selçuk Üniversitesi Sosyal Bilimler Enstitüsü, Konya.

Döngel, M. (2009). Hafif düzeyde zihin engelli öğrencilere yazma becerilerinin kazandırılmasında kullanılan ögrretim yöntem ve tekniklerine ilişkin ögrretmen görüşlerinin değerlendirilmesi (Yayınlanmamış yüksek lisans tezi). Selçuk Üniversitesi Sosyal Bilimler Enstitüsü, Konya.

Duman, N. (2006). Hikaye haritası yönteminin eğitilebilir zihinsel engelli öğrencilerin okuduğunu anlama becerileri üzerindeki etkisi (Yayınlanmamış yüksek lisans tezi). Abant İzzet Baysal Üniversitesi Sosyal Bilimler Enstitüsü. Bolu.

Dündar, R. (2006). Orta düzeyde zihin engelli çocuklara ses temelli ve cümle çözümleme yöntemlerinin etkililiklerinin karşılaştırılması (Yayınlanmamış yüksek lisans tezi). Hacettepe Üniversitesi Sağlık Bilimleri Enstitüsü. Ankara.

Eripek, S. (1989). Alt özel sınıf öğrencilerinin ilkokul sınıfları düzeyinde sesli okuma başarılarının değerlendirilmesi, Anadolu Üniversitesi Eğitim Fakültesi Dergisi, 2 (2), 125-140. 
Eripek, S.(1998). Özel eğitim (Edit. S. Eripek). Zihin engelliler. Eskişehir: Anadolu Üniversitesi Açıköğretim Fakültesi Yayınları.

Ferah, A. (2009). Türkçe ilk okuma yazma göstergelerinin irdelenmesi. Türk Dili Dil ve Edebiyat Dergisi, XCVII (688), 348-362.

Gander, M. J. ve Gardiner, H. W. (2007). Çocuk ve ergen gelişimi. (Çev. B. Onur). Ankara: İmge Kitabevi.

Glesne, C. (2012). Nitel araştırmaya giriş. (Çev. Ersoy A. ve P. Yalçınoğlu). Ankara: Anı Yayıncılık

Güldenoğlu, İ. (2008). Karşılıklı öğretim tekniğinin hafif derecede zihin engelli öğrencilere okuduğunu anlama becerilerinin ögretiminde etkililiğinin ve sürekliliğinin incelenmesi. (Yayınlanmamış yüksek lisans tezi),Ankara Üniversitesi Eğitim Bilimleri Enstitüsü, Ankara.

Güler, Ö. (2008). Zihin engelli öğrencilerin okuduğunu anlama becerisinde okuma öncesi, sirası ve sonrasında uygulanan okuduğunu anlama tekniklerinin etkililiklerinin karşılaşstırılması (Yayınlanmamış yüksek lisans tezi). Gazi Üniversitesi Eğitim Bilimleri Enstitüsü, Ankara.

Güneş, F. (2005). Niçin ses temelli cümle yöntemi? Eğitimde Yansımalar VIII: Yeni İlköğretim Programlarını Değerlendirme Sempozyumu'nda sunulmuş bildiri, Erciyes Üniversitesi, Kayseri.

Hall, N. (1987). The emergence of literacy. Portsmouth: NH. Heinemann Educational Books

Katims, D. S. (1996). The emergence of literacy in elementary students with mild mental retardation. Focus on Autisim and Other Disabilities, 11 (3), 147-158.

Karaca, M. A. (2018). Özel eğitim sınıflarında öğrenim gören hafif düzey zihinsel yetersizliğe sahip olan öğrencilere yönelik okuma öğretiminde karşılaşılan güçlüklerin incelenmesi. Akademik Sosyal Araştırmalar Dergisi, 6, (80). 489-503.

Koballa, T., Graber, W., Coleman, C., \& Kemp, C. (2000). Prospective gymnasium teachers conceptions of chemistry learning and teaching. International Journal of Science Education, 22(2), 209-224.

Keklik, İ. (2011). Eğitim psikolojisi. İ. Yıldırım) (Ed.), Bilişsel gelişim. Ankara: Anı Yayıncılık

Köroğlu, E. (1997). Psikiyatri temel kitabı. (Edit. E. Köroğlu ve C. Güleç). Ankara: HYB.

Kırcaali-İftar G., ve Uysal, A. (1999). Zihin özürlü öğrencilere özel eğitim danışmanlığı aracılı̆̆ıyla uygulanan resimli fişlerle okuma yazma öğretiminin etkililiği. Özel Ĕgitim Dergisi, 2 (3), 313.

Marton, F. (1986). Phenomenography: A research approach to investigating different understanding of reality. Journal of Tought, 21(3), 28-49

Mascolo-Glosser, F. (2015). Reducing challenging behaviors in intellectually disabled individuals: a comparison of organizational culture and treatment approach (Published master thesis). Walden University, New York State.

Mastropieri, M. A. and Scruggs, T. E. (2016). Kaynaştırma sınıfı: Etkili farklılaştırılmış öğretim için stratejiler (Çev. Ed. M. Şahin ve T. Altun). Ankara: Nobel Yayıncılık.

MEGEP (2016). Çocuk gelişimi ve eğitimi: Zihinsel yetersizlikler http://www.megep.meb.gov.tr/mte_program_modul/moduller/Zihinsel\%20Yetersizlikler.p df, (Erişim tarihi: 12.09.2018).

MEB (2018). 30471 Sayılı ve 2018 Tarihli Özel Eğitim Hizmetleri Yönetmeliği. 
Merriam, B. S. (2014). Nitel araştırma. 3. Basımdan Çeviri (Çev. Edit. S. Turan). Ankara: Nobel Yayıncilik.

Merriam, S. B., \& Tisdell, E. J. (2015). Qualitative research: A guide to design and implementation (4. Edition). San Fransisco: Jossey Bass.

Metin, H. (2015). Zihinsel engelli bireylere kavram öğretiminde kullanulan etkili ögretim yöntemlerinin karşılaştırmal olarak incelenmesi (Yayınlanmış yüksek lisans tezi). Necmettin Erbakan Üniversitesi, Konya.

Özkan, Ş.Y., Öncül, N. ve Kaya, Ö. (2013). Effects of computer-based instruction on teaching emergency telephone numbers to students with intellectual disability. Education and Training in Autism and Developmental Disabilities, 48 (2), 200-217.

Lincoln, Y.S. and Guba, E.G. (1985). Naturalistic inquiry. California: SAGE.

Punch, K. (2014). Sosyal araştırmalara giriş: Nicel ve nitel yaklaşımlar. 3. Baskı (Çev. D. Bayrak, H. B. Arslan ve Z. Akyüz). Ankara: Siyasal Kitabevi.

Ritchie, J. Lewis, J. ve Elam, G. (2006). Designing and Selecting Samples (Eds. J. Ritchie \& J. Lewis). Qualitative Research Practise A Guide for social science students and re-searchers. Thousand Oaks, CA: Sage Publications.

Sever, S., Kaya, Z. ve Aslan, C. (2011). Etkinliklerle Türkçe öğretimi (2. Bask1). İzmir: TUDEM Yayınları.

Shaywitz, S. (2003). Overcoming dyslexia: A new and complete science-based program for read ing problems at any level. New York: Knopf.

Sucuoğlu, B. (2013). Zihin engeli tanımları sınıflandırma. B. Sucuoğlu (Edit). Zihin engelliler ve eğitimleri. 4. Bask1. Ankara: Kök Yayıncılık, s.49-86.

Sinclaire, E. Forness, S. (1983). Classification: Educational issues (Edit.L. Matson) Handbook of Mental Retardation, New York: Pergaman Press.

Söhmen T ve Türkbay T. (2003). Engelli Çocuklar. Ankara: GATA Basımevi

Sulak, S. E. (2018). İlkokuma yazma öğretimi (Edit. F. Güneş ve S. Sidekli). İlkokuma-yazma ögretim yöntemleri. (103-153), Ankara: Eğiten Kitap.

Şengül, H. (2008) Özel eğitim öğretmenlerinin zihin engelli çocuklara okuma-yazma öğretiminde kullandıkları yöntemlerin belirlenmesi. (Yayınlanmamış yüksek lisans tezi). Marmara Üniversitesi Eğitim Bilimleri Enstitüsü, İstanbul.

Şengül, H , Akçin, N . (2010). Opinions of special education teachers about teaching reading and writing to mentally retarded children. Ankara University Journal of Faculty of Educational Sciences (JFES) , 43 (2) , 1-26.

Teale, W. H., \& Sulzby, E. (Eds.). (1986). Emergent literacy: Writing and reading. Norwood: NJ Ablex.

Tekinarslan, İ. Ç. (2010). Özel eğitime gereksinimi olan öğrenciler ve özel eğitim. (Ed. İ. Diken) Zihinsel yetersizliği olan ögrenciler (137-165), Ankara: Pegem A Yayınc1lık.

Tokta, C. ve Avcıoğlu, H. (2012). Zihinsel yetersizliği olan kaynaştırma öğrencilerine okuma-yazma öğretiminde kullanılan ses temelli cümle yönteminin etkililiğine ilişkin öğretmen görüşleri. Turkish International Journal of Special Education and Guidance ve Counceling, 1(1), 1124. 
Uyanık ve Tural. E. (2003). Mental retarde çocuklarda bağımsızlık ölçümü ve çocuk özür değerlendirme envante'nin güvenirlik ve uyum geçerliği, Fizyoterapi Rehabilitasyon, 14 (2), s 72-79.

Villanueva M.G., Taylor J., Therrien W. and Hand B. (2012). Science education for students with special needs. Studies in Science Education, 48(2), 187-215

Werts, M.G., Culatta, R.A., \& Tompkins, J.R. (2007). Fundamentals of special education: What every teacher needs to know. Upper Saddle River, N.J.: Pearson/Merrill Prentice Hall.

Yıkmış, A., Terzioğlu, N.K., Kot, M., Aktaş, B. (2017). Özel eğitim öğretmenlerinin derslerde oyun ve şarkıyı kullanma durumları. Abant İzzet Baysal Üniversitesi Eğitim Fakültesi Dergisi, 17(3), 1548-1583.

Yıldırım, P. ve Albuz, A. (2010). Zihinsel engelli çocuklara kavram öğretiminde müziğin kullanımına ilişkin öğretmen görüşleri. E- Journal of New World Sciences Academiy, 5,(4), 233-244

Yıldırım, A. ve Şimşek, H. (2013). Sosyal bilimlerde nitel araştırma yöntemleri (Genişletilmiş 9. Bask1). Ankara: Seçkin Yayıncılık. 